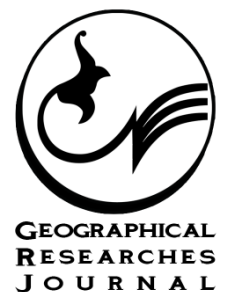

\title{
Role of the Place on Information and Communication Technology Effectiveness on Women's Gender Identity; a Case Study of Ahvaz City, Iran
}

\section{ART ICLE INF O}

\section{Article Type}

Original Research

\section{Authors}

Sajjadian $N .^{* 1} P h D$

Nemati M. ${ }^{1} P h D$,

Gashtil F. ${ }^{1} M A$

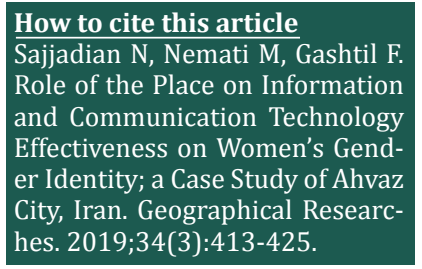

${ }^{1}$ Department of Geography and Urban Planning, Faculty of Literature and Humanities, Shahid Chamran University, Ahvaz, Iran

\section{*Correspondence}

Address: Faculty of Literature and Humanities, Golestan Boulevard, Ahvaz, Iran. Postal code: 6135783151 Phone: +98 (35) 35220281

Fax: +98 (61) 33332024 nsajadian@yahoo.com

\section{Article History}

Received: May 4, 2019

Accepted: August 17, 2019

ePublished: October 2, 2019

\section{A B S T R A C T}

Aims \& Backgrounds Gender geographers suggest that the formation of sexual identity is made through place differences. On the other hand ICT with an international world full of unlimited resources is competing with traditional and environmental resources in formation of women's sexual identity through modernism. Women in Ahvaz like other women in the world are not excluded and are challenging selecting their sexual identity through thousands of traditional and modern resources.

Methodology This study is in the year 2017 trying to find out that today women's sexual identity in different neighborhoods of This City is influenced by which resource and how does place or information technology and communication effect on their sexual identity. The nature of this study is applied -theoretical and its method is descriptive - analytical. The basis of this study is the Field of behavioral and gender geography. The data collection method is a researcher made questionnaire and it's statistical Society are women over the age of 15 in Kianpars, Golestan, Manbaab neighborhoods

Findings The results of various statistical tests such as Anova,Ttest, Tukey,... showed that the impact of information and communication technology on the sexual identity of women in the neighborhood is not the same and does not follow a specific pattern.But the place variable in this field acts as a moderator variable.Women's sexual identity is more oriented towards modernity in places of higher levels of development (Kianpars).In second level neighborhoods (Golestan) women's sexual identity does not show a dominant tendency towards modern or traditional and it is measured at the intermediate level and a combination of these two.But invert level places (Manba $\mathrm{Ab}$ ) women's sexual identity tents to oriented weakly towards being traditional.

Conclusion Spatial values affect women's gender identity building. And the place plays a moderating role in the impact of women on ICT.

Keywords Place; Gender Identity; ICT; Gender Geography; Ahvaz

\section{CIT A T I O N L INKS}

[Abassi Ghaderi, et al; 2013] The effect of the internet on national ...; [Ahmadzadeh Kermani; 2011] Rethinking in culture and ...; [Adlipoor; 2013] Sociological explanation of ...; [Afsharkhan \& Rezaei Karmajani; 2017] Investigating the role of social identity ...; [Ahmadi, et al; 2015] Media and reproduction of women's ...; [Bigdeli \& Sharifi; 2008] An introduction to the ...; [Bostan; 2009] Islam and gender ...; [Bastani \& Mousainejad; 2013] Gender identity of men and ...; [Behnam; 2012] Iranians and Modern ...; [Damanbagh; 2013] Geographic analysis selected ...; [Deputy of Planning and Development of Ahvaz Municipalities; 2018] Ahvaz Municipality ...; [Flint; 2006] Introduction to ...; [Ghanavati; 2013] Geographic analysis of social ...; [Ghanbari; 2015] Geography and place identity in ...; [Grewal; 2017] Mass media and the ...; [Gregory, et al; 2000] The dictionary of human ...; [Giddens; 2012] Gender ...; [Giddens; 1992] Modernity and self-Identity ...; [Hekman; 2007] Identity crises, identity, ...; [Hafez Nia et al; 2008] Politics and ...; [Hafez Nia; 2009] Introduction to Research Methods ...; [Hatami \& Mazhabi; 2011] Media and women's ...; [Hemati \& Aslani; 2015] Effective factors of ...; [Henson \& Narula; 2009] New communication ...; [Jackson; 1993] Doing what comes ...; [Jay Dunn; 2005] The social critique of ...; [Jenkins; 2012] Social ...; [Khajeh Noori, et al; 2016] The relationship ...; [Khani; 2007] In the field of gender ...; [Mohammadi Asl; 2011] Gender and ...; [Movahed \& Zarifi; 2011] Investigating the ... [Mehdizadeh \& Tofighi; 2006] Presentation relationship ...; [Nemati; 2011] Transformation of ...; [Nikkhah Ghamsari \& Mansourian Ravandi; 2016] Research of relationship between ...; [Oraki; 2015] Geographical analysis of ...; [Papoli Yazdi \& Sahaghi; 2002] Tradition, modernity, ...; [Persian Language and Literature Academy; 2018] Word Dictionary ...; [Seyfollahi \& Razeghian; 2008] Social factors affecting ...; [Rezapour, et al; 2016] Investigating the relationship ...; [Sadeghi Givi \& Parhizkari; 2010] Explaining the ...; [Taban, et al; 2013] Identity and location, ...; [Varmaghani, et al; 2015] The relationship ...; [Lorber; 2000] Using gender to ...; [Malesevic \& Haugaard, editors; 2002] Making Sense of Collectivity ...; [Caplan, et al; 1997] Gender Differences ...; [Simmons; 2008] Marketing to Postmodern ...; [Thomas \& Cross; 2007] Organization as place ...; [Woodward; 2004] Ouestioning Identity ...; [Wynn \& katz; 1998] Hyperbole over Cyberspace: Self-Presentation ...; [Zaki; 2016] Internet and Iranian .... 
مكان، فضا و مرزهاى زندگى تحت تأثير قرار كَرفت Nikkhah] .Ghamsari \& Mansourian Ravandi, 2016:108] دسترسى مداوم به رسانهها و فاوا، فرد را از مكان خود جدا و و به به

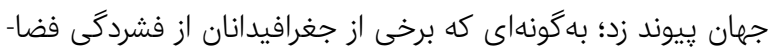

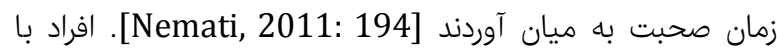
منابع هويتيابى متكثرى روباروو شدند و هويتيابى شكلى غير

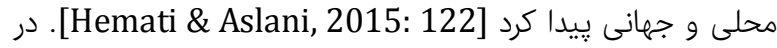
اين ميان زنان كه در طول تاريخ نسبت به مردان، همواره امتيازات

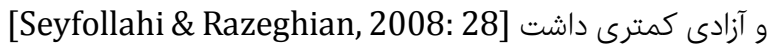

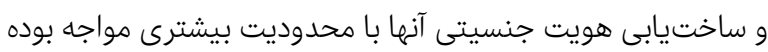
است بيشتر تحت تأثير اين مساله قراركرفتهانداند.

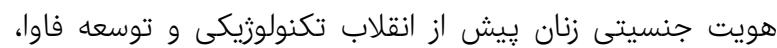

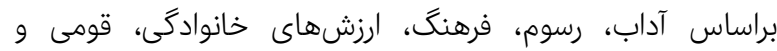

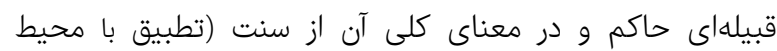

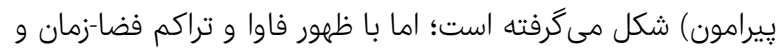

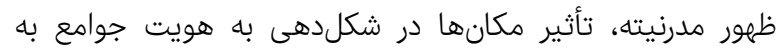
خصوص زنان كمرنگ و كم اثر شد [Taban et al, 2013: 79] تكنولوزىهاى مدرن و فاوا، هويت برساختهاى (Artificial) را كه

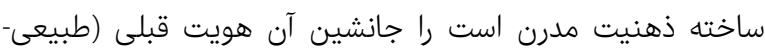

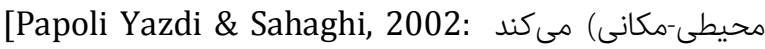
[21 اين مساله در اولين مقاله اولين شماره فصلنامه تحقيقات

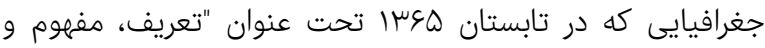

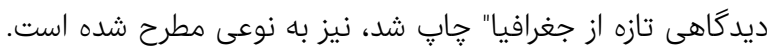

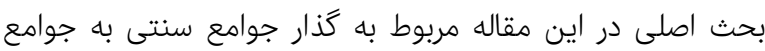

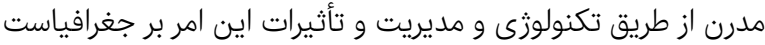

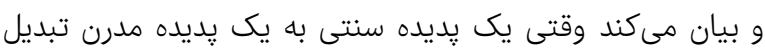

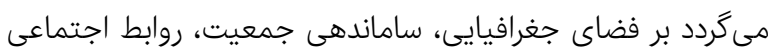
[Papoli Yazdi \& Sahaghi, و اخلاقيات تأثير مستقيم دارئ [2002: 9] غلامحسين فرنود در كتاب "در بساط نكتهدانان"

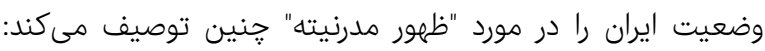

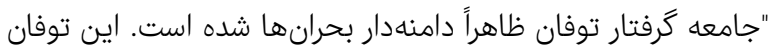

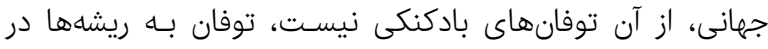

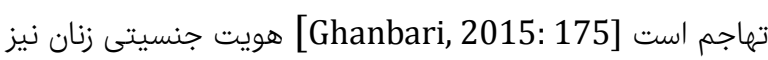
از مقوله مدرنيته و تأثير آن دور نمانده است.

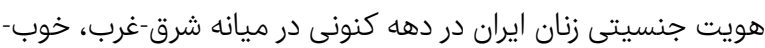

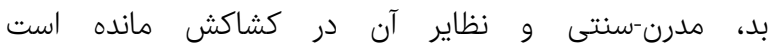
[Mohammddi Asl, 2011: 199]

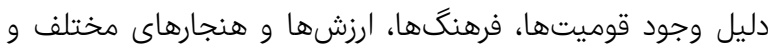

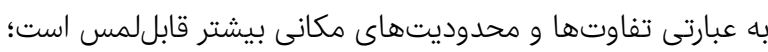

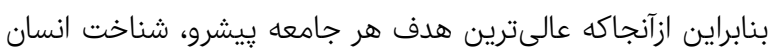

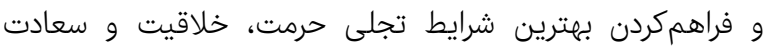

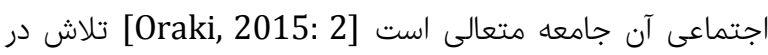
جهت شناخت هويت جنسيتى زنان و منابع شكلدهنده آن بهن آعنوان آنسان زيربناى اصلى ساخت هويت، بر بيشبرد اين اهداف كمك شنايع شايانى
نقش مكان در اثرگذارى فناورى اطلاعات و و ارتباطات بر هويت جنسيتى زنان؛ مطالعه موردى

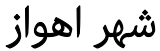

PhD * ناهيد سجاديان كروه جغرافيا و برنامهريزى شهرى، دانشكده ادبيات و علوم انسانى، دانشكاه شهيد جمران، اهواز، ايران

PhD مرتضى نعمتى اهواز، ايران كروه جغرافيا و برنامهريزى شهرى، دانشكده ادبيات و علوم انسانى، دانشگاه شهيد جمران، اهواز، ايران

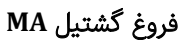
كروه جغرافيا و برنامهريزى شهرى، دانشكده ادبيات و علوم انسانى، دانشكاه شهيد جمران، اهواز، ايران

جكيده اهداف و زمينهها: شكل خيرى هويت جنسيتى از طريق تفاوتهاى مكانى ايجاد

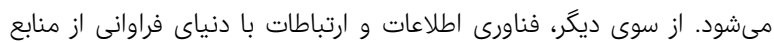

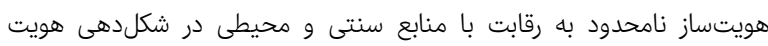

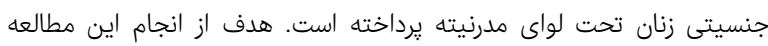

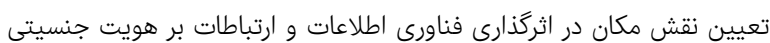
زنان شهر اهواز بود.

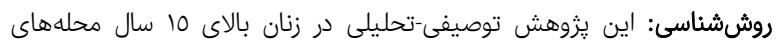

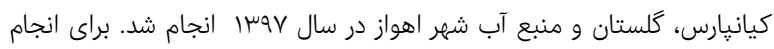

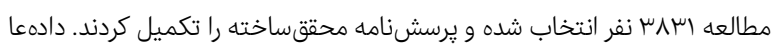

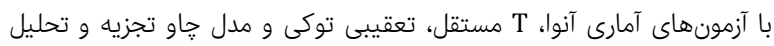

شدند.

يافتهها: سطوح متفاوت مكانى در فرآيند شكل گيرى هويت جنسيتى زنان نقش

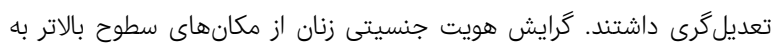

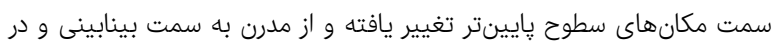

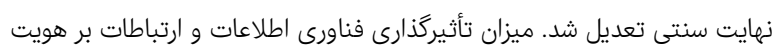

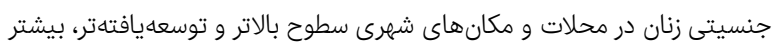

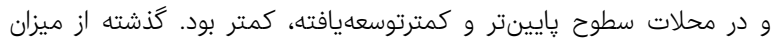

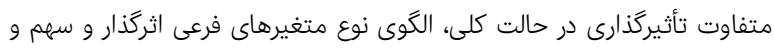

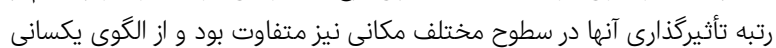

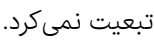

نتيجهگيرى: ارزشهاى مكرد مانى بر ساخت هويت جنسيتى زنان اثر دارد و در

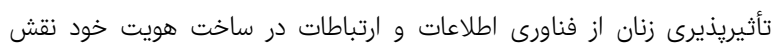

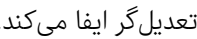
كليدوازمها: مكان، هويت جنسيتى، فاوا، جغرافياى جنسيتى، اهواز

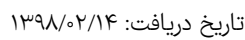

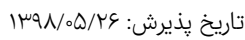

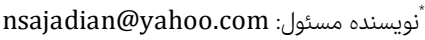

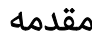

مكانها، مراكز اصلى تجربه بلافصل از جهان هستند و تا ييش از

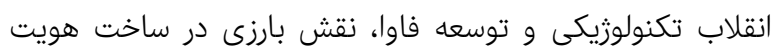

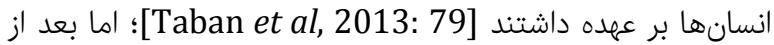
ظهور و توسعه فاوا ييوند عناصر اساسى منابع هويتساز يعنى زمان، 


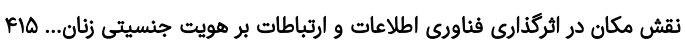

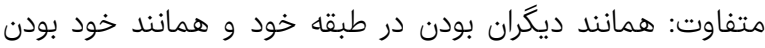

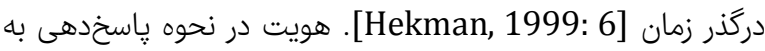

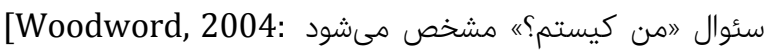

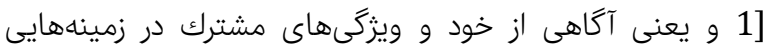
مانند:"طبقات اجتماعى، مذهب، قوميت و جنسيت

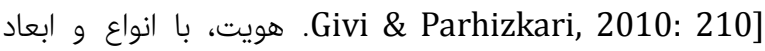
مختلف فردى (شخصى)، خانوادگى، اجتماعى، ملى، سياسى و اقتصادى و جنسيتى شناخته مىشود؛ هريك از اين ابعاد هويت،

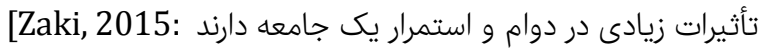
جنس ويزگىهاى زيستشناختى متفاوت مرد و و زن است

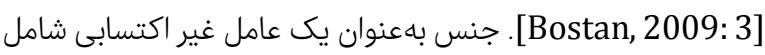
ويزگگهاى زيستى، كالبدى، جسمانى و كروموزومى است كه مرد و

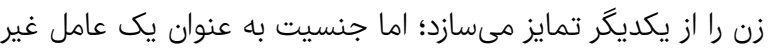

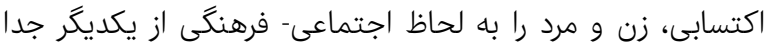

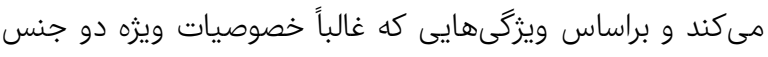
محسوب مىشود، شكل مى مَيرد [Caplan et al, 1999: 47]. جنسيت" آشكارترين وجه هويت فردى است كه در تعامل با ديكران ساخته مىشود [Aghili et al, 2015: 2] ولى ويزّى فطرى افرديت افراد

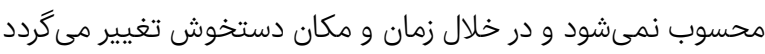

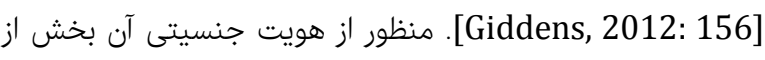
رفتارها و نكرشهاى فرد نسبت به خويش است كه تحت تأثير

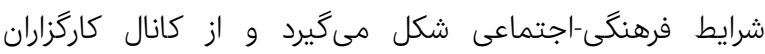

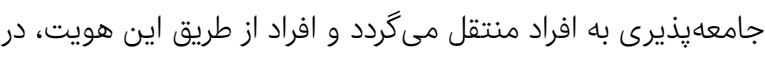

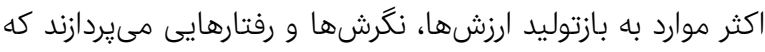

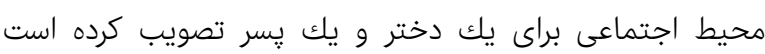

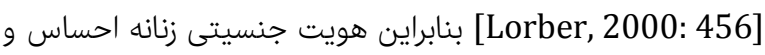
تصويرى است كه شخص از زنانكى خود دارد و شامل انتظاراتى

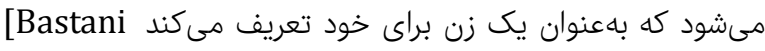

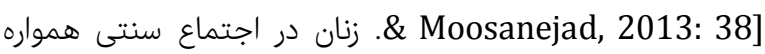

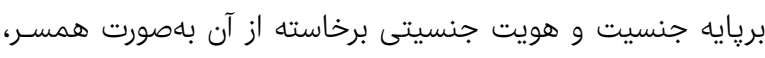

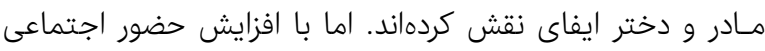

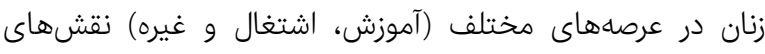
سنتى آنها در بسيارى از جوامع امروزى مورد يرسش قرارگرفته استان.

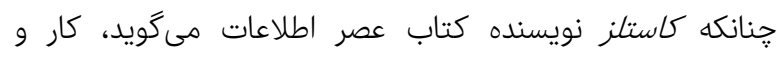

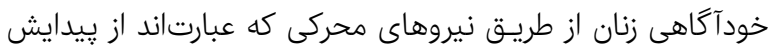

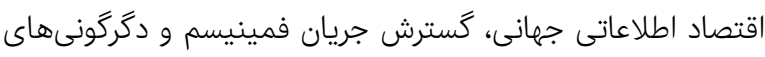

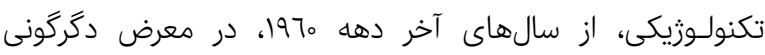

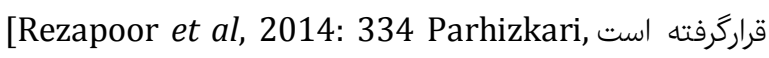

2010: 210]

در جوامع ييشامدرن و در فرهنگهاى سنتى، هويت جنسيتى از

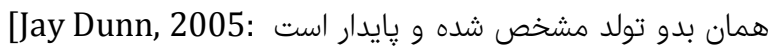

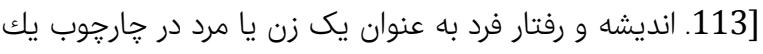

مىكند؛ لذا اين يزوهش در بى اين اهداف است كه دريابد در حال

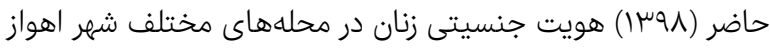

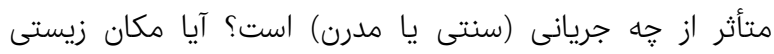

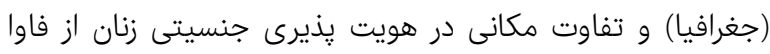

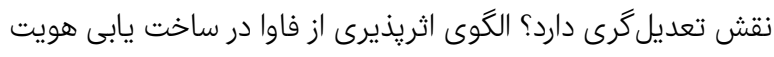

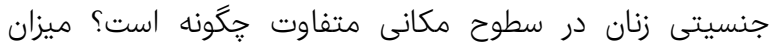

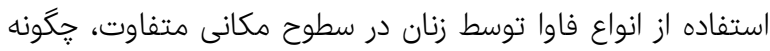

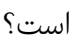
مكان صاحبنظران حوزه جغرافياى انسانى بر اين باورند كه فضا از جهان

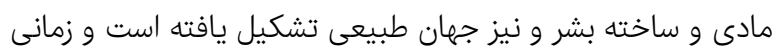

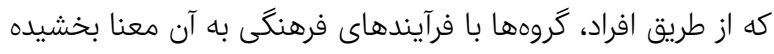

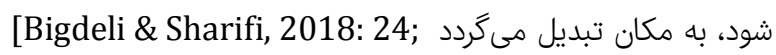

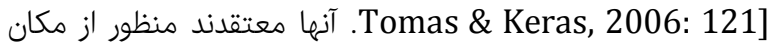
صرفاً پديدهاى نيست كه در ذهن افراد نقش بسته باشد، بلكه

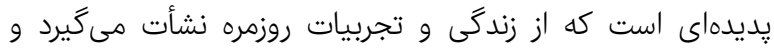

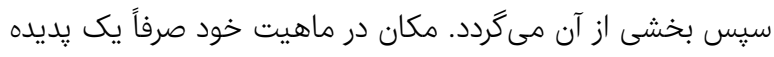

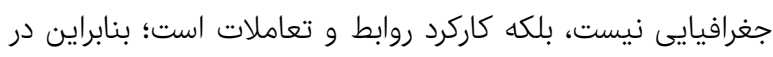

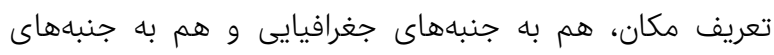
اجتماعى آن توجه مىشود و براساس معنايى كه افراد و كروهها به جنه

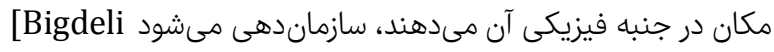
\& Sharifi, 2018: 246]

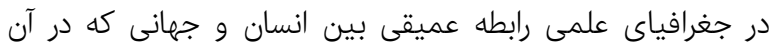

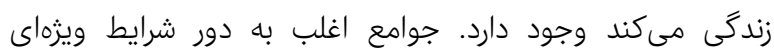

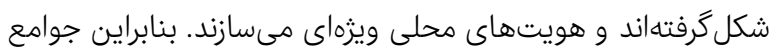
[Race \& Flint, 2001: محلى در يك شكل دادهده قرار ندارند ] سياست، اجتماع، ارتباطات، خانواده، هويت، نقشها و باورهاى

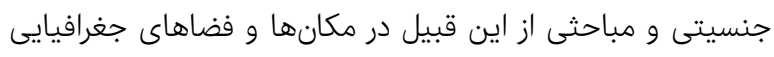

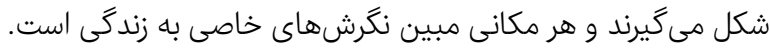
تمايزات و تفاوتهاى مكانى و فضايى هم در مقياس بزرگت-ساكنان

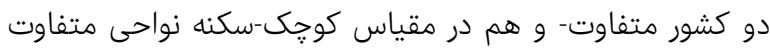

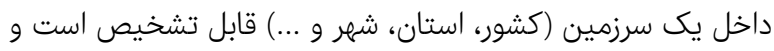

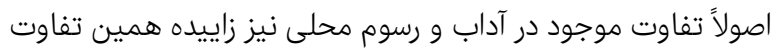

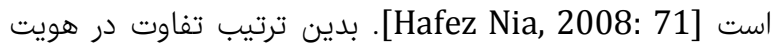
بهطوركلى و هويت جنسيتى مردم بهطور خاص تحت تأثير اين تفاوتها قابلانتظار است.

هويت مفهوم هويت كه ريشه در علوم رياضى دارد، به شباهتهاى موجود بين دو روش و ״تفاوت درصد صفر" در رياضيات ارجاع داده مى هى دود.

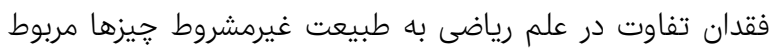

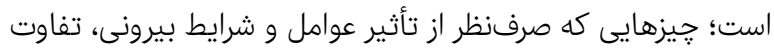

[Malesevic \& Haugaard, بسيار ناجيز باهم داشته باشنئ

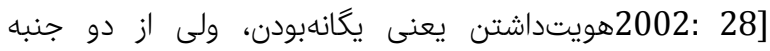


كامييوتر مرتبط باهم و متصل به شبكه مخابراتى، اينترنت و

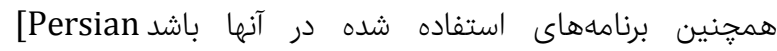
هصر Language and Literature Academy, 2017: 315] ول فاوا با تكنولوزىهاى ارتباطى فيلم، راديو و تلويزيون و ويدئو

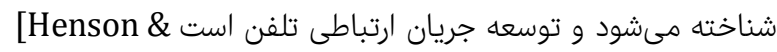
Narola, 2011; Adlipoor, 2012: 51] عصر دوم فاوا كه از ديد نظريهيردازان با ظهور و شكلگيرى نوع جديدى از جامعه همراه شده است، از طريق ادغام تكنولوزىهاى جديد ارتباطى ماهوارهاى با كامييوتر و اينترنت ظاهر شده آنداه است.

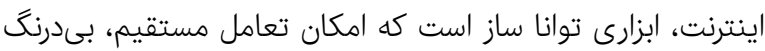

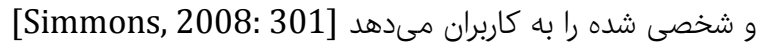

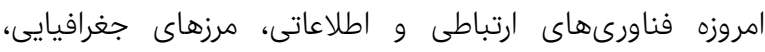

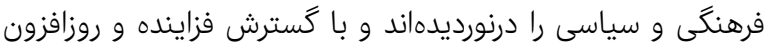

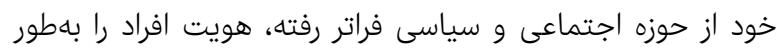

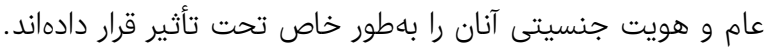

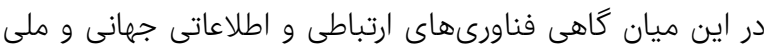

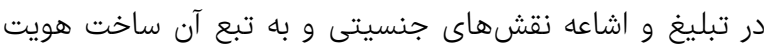

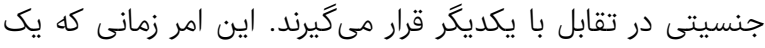
كشور شرايط فرهنكى متفاوت و خاصى داشته باشد مثل مثل ايران-

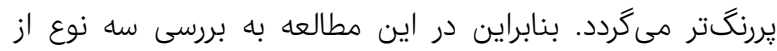

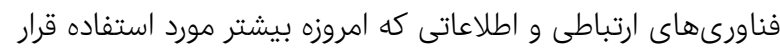

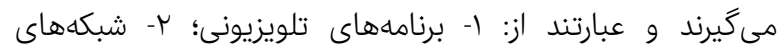

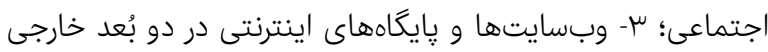

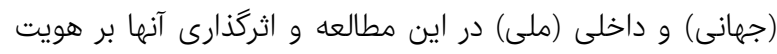

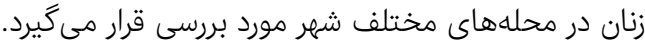

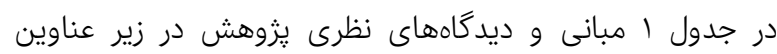

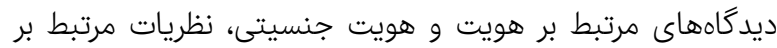

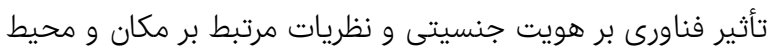
بر هويت و هويت جنسيتى بهطور خلاصه بيان شده است.
جهانبينى محدود محصورشده و مسير زندگى بسته بهانه به جنس فرد

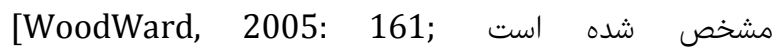
] نخستين هويتى كه براى زن در نظر گرفته مىشود، هويت سنتى

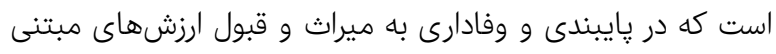

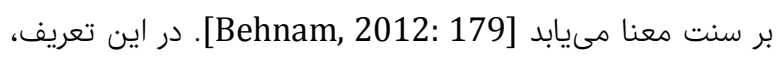
زن موجودى است ساده و باعفت كه فعاليتهايش محدود به خانه

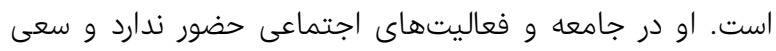
مىكند وظايف خود را بهعنوان مادر و همسر بهخوبى إئ ايفا كند Ghigivi \& Parhizkari, 2010: 218] [Sade در جامعه مدرن، محل وقوع فرايندهاى تكوين هويت به حيات

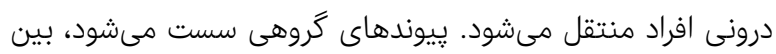

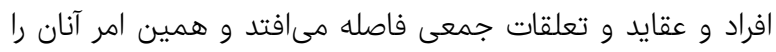

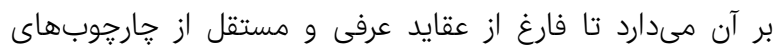

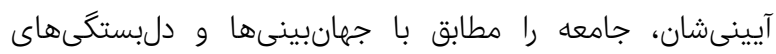

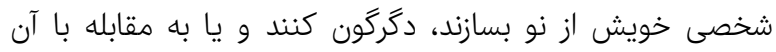

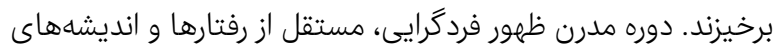

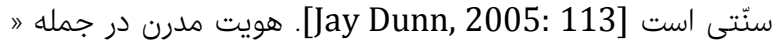
من فكر مىكنم، پِ هستم " دكارت به تكامل رسيده است.

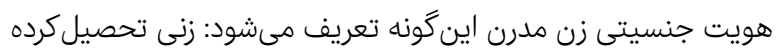

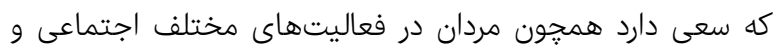

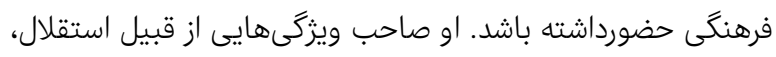

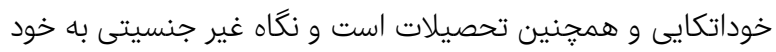
دارد، درنتيجه رابطه او با همسرش بهائ تجاى اطاعت، رابطه همكارى و و

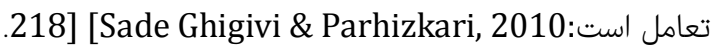

فناورىهاى ارتباطى و اطلاعاتى تلى إنى

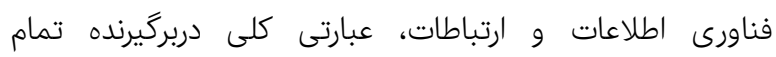

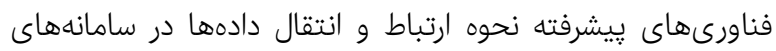

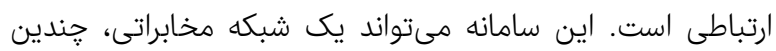

جدول () مبانى و ديدكاههاى نظرى يزوهش

\section{ديدگاoها}

هويت را محصول فرايندى مستمر ميان خود و ديگرى مىداند و معتقد است فرد در عرصه مواجها و رويارويى با ديگران به لحاظ دهاظ

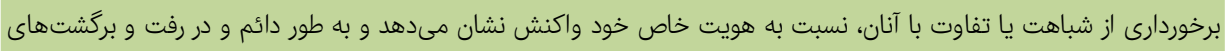

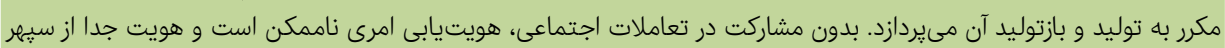

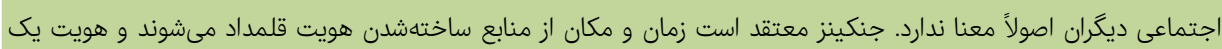

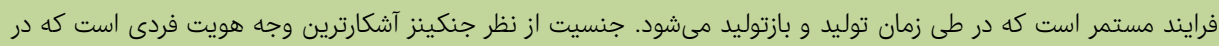
تعامل با ديكران ساخته مىشود و قطعاً هويتى جمعى است است دمان.

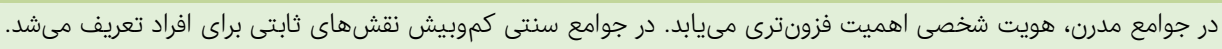

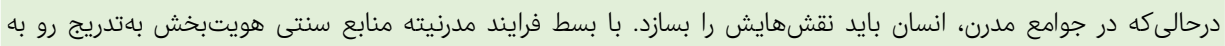

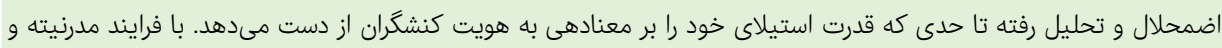

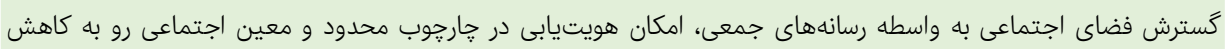

اسض. حضور در شبكهاى مجازى از سويى فشارهاى ناشى از هماهنكى "خوده با انتظارهاى جمعى را در دنياى واقعى كاهش مى إدهد

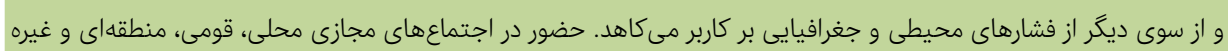

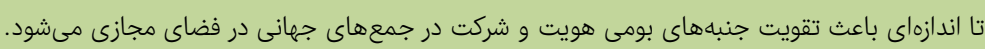

عنوان نظريه و مؤلف

نظريه هويت اجتماعى

[Jenkinz, 2013]

[Afsharkohan \& Rezaei

Karmanji 2017]

[Jenkinz, 2011]

نظريه هويت آنتونى گيدنز

[Giddens, 1992]

[Giddens, 2010]

رين كلد

[Adlipoor, 2013] 


\section{ديدكاهها}

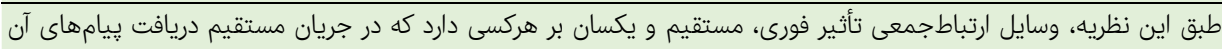

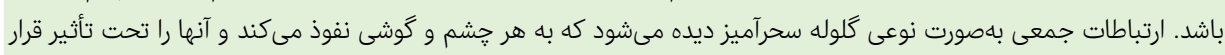

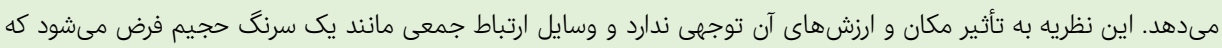

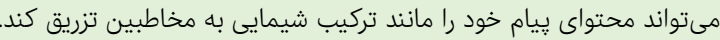

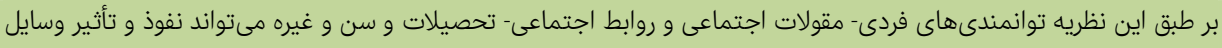

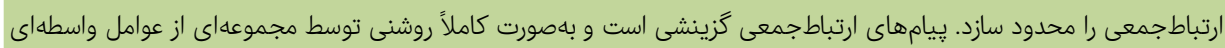

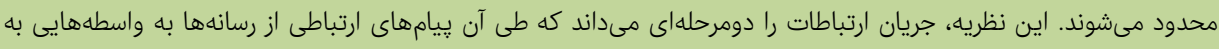

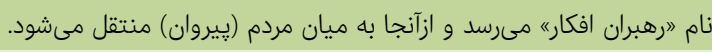

نظريه تزريقى (كلوله جادويى) [Deflour \& Denis, 2008] نظريه استحكام يا تأثير محدود
[Ahmadzade kermani,
2011]

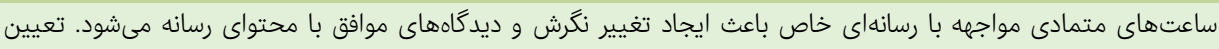

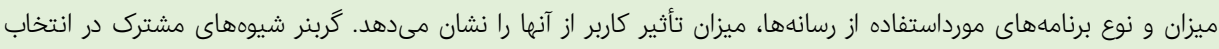

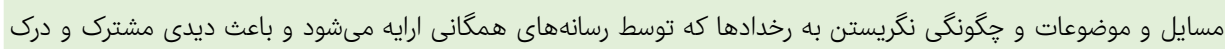

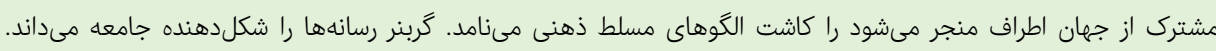

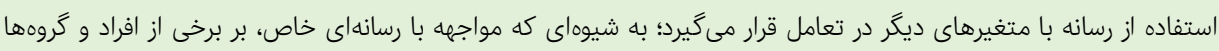

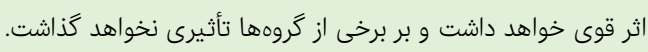

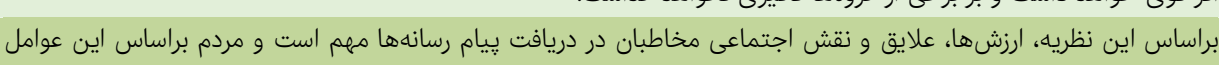

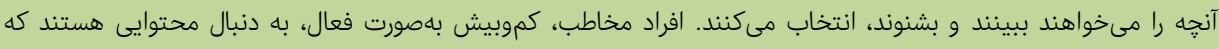

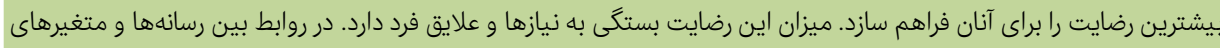

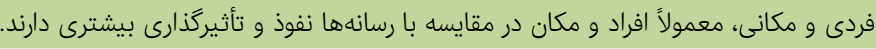

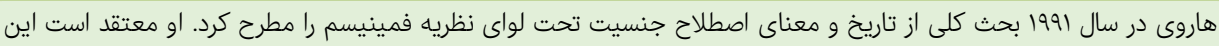

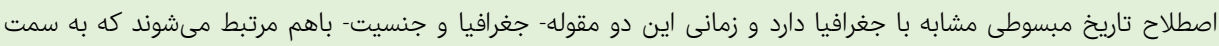

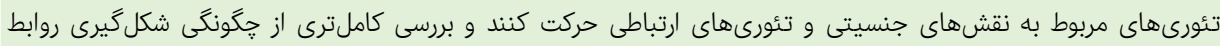

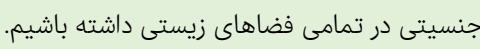

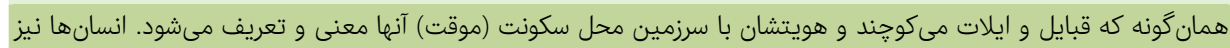

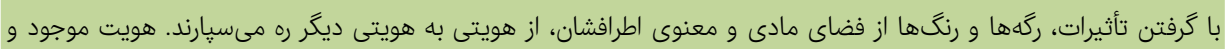

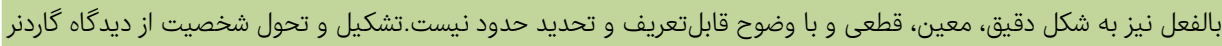

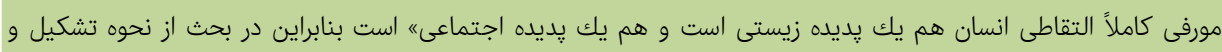

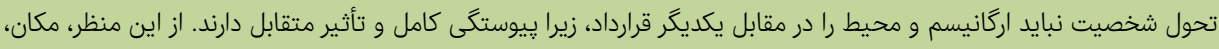

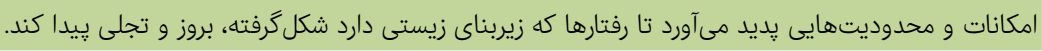

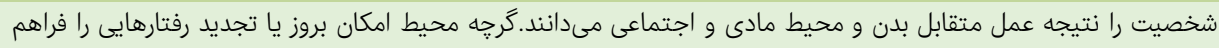

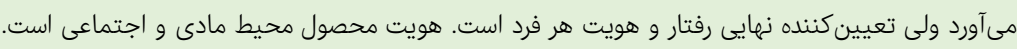

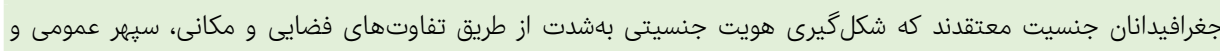

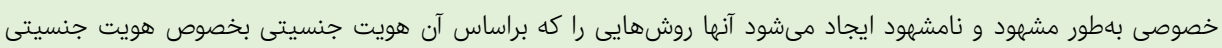

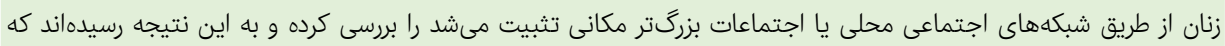

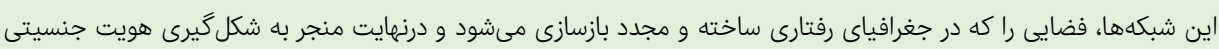

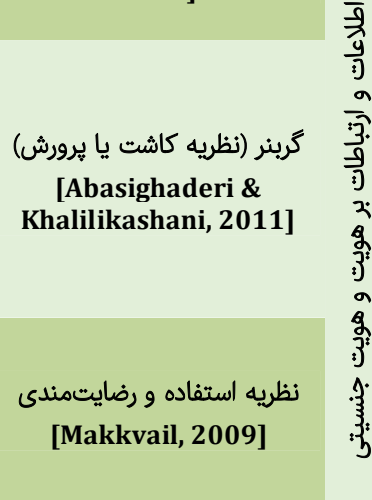

ديدگاه ديويد هاروى [Gregory et al, 2000]

ديدگاه جغرافيدانان فمينيست

نظريه گَاردنر مورفى

[Taban et al, 2013]

اريك فروم و سوليوان

[Taban et al, 2013]

[Jakson, 1993] از يايايى مورد قبولى برخوردار بوده است. سئوالات يرسشنامه مذكور

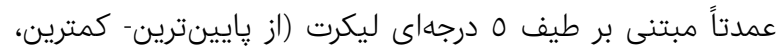

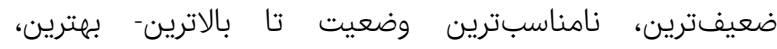
مطلوبترين وضعيت) بوده كه در نهايت با كدگذارى از عدد إنترين (يايينترين) تا ه (بالاترين) بهصورت كمى بوده تعريف شدند. جامعه آمارى نظرى يزوهش، كل جمعيت زنان بالاى 10 سال شهر

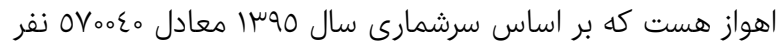
[www.amar.ir] انجام مطالعات درنهايت سه محله از شهر اهواز به عنوان نمونههاى

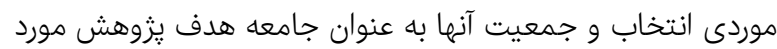
مطالعه قرار گرفت. حجم كل نمونه نيز با استفاده از فرمول كوكران
يزوهش حاضر كه اساس آن در حيطه جغرافياى رفتارى و جنسيت

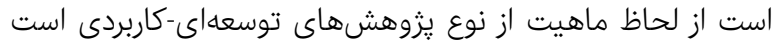

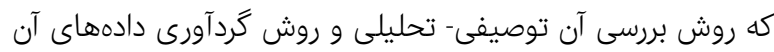

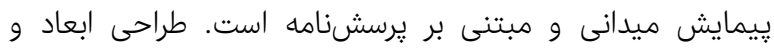

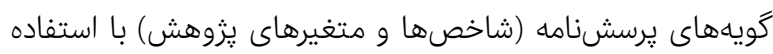
از تركيب مطالعات نظرى و دستاوردهاى يزوهشهاى برهاى تجربى مشابه

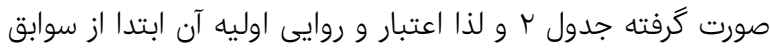
تحقيقاتى و نظرى موجود اخذ شده و سيس با استفاده از نظر صاحبنظران و متخصصين مرتبط (عمدتاً متخصصين دانشگاهى)

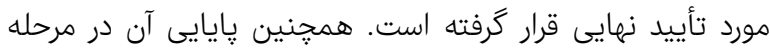

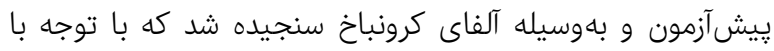


محله كيانيارس كه براساس سرشمارى سال 90سا، داراى VA.00 نفر

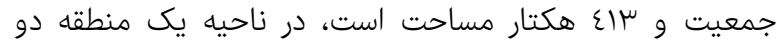

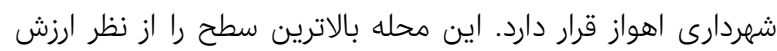

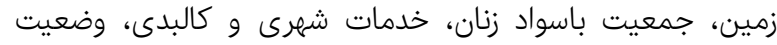
اقتصادى و اجتماعى را در بين محلات شهر اهواز دارا است. ساكنان اين محله از رفاه بيشترى نسبت به اقشار ساكن در در محلات دات ديكر شهر اهواز برخوردارند. اين محله بهطور گسترده به عنوان مكان تفريح

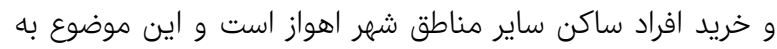
]ونق آن كمك زيادى نموده است Research Deputy, Shahid

.Chamran University of Ahvaz, 2015: 20] محله كلستان در ناحيه جهار منطقه جهار قرار دارد. مساحت آن 7هـ

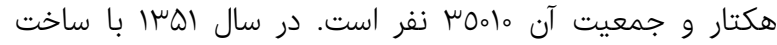

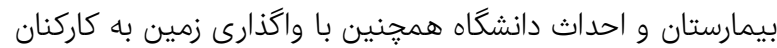

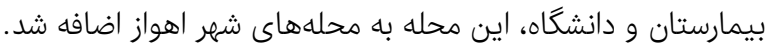

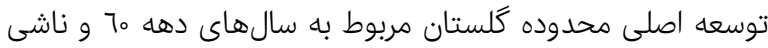

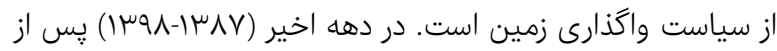
اشباعشدن محلههاى تجارى اصلى شهر، اين محله توسعه زيادى

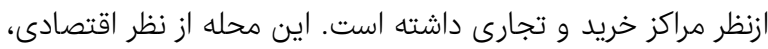

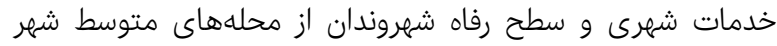

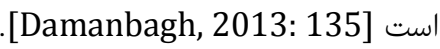
منبع آب در شرق شهر اهواز و در ناحيه جهار منطقه هفت شهردارى

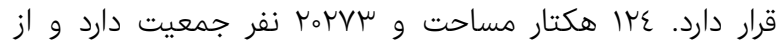
اجتماعات حاشيانشينى به شمار مىآيد. اين محله از جوانترين

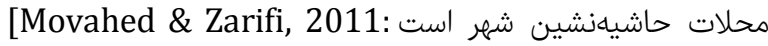
156; Ghanavati, 2013: 156]

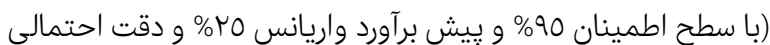
مطلوب 0\%) تعداد اسمץ به دست آمده است كه به نسبت حجم

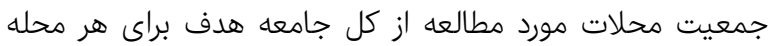

محاسبه شد (جدول س). با توجه به عدم امكان تهيه جارجوب ندون نمونه

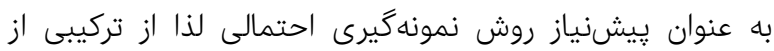

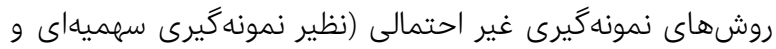

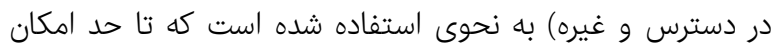
تمامى گستره محلات مورد بررسى به شيوه حضورى و مراج مراجعه مستقيم مورد يوشش قرار گيرد.

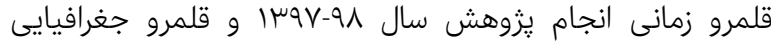

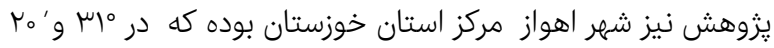

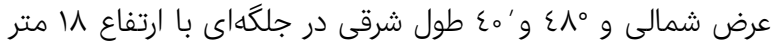
از سطح دريا قرار دارد. اين شهر مركز شهرستان اهواز است و ودار داراى

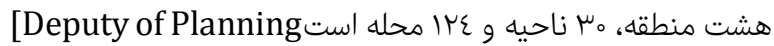
.and Development of Ahwaz Municipality, 2017: 6] همانطور كه يِشتر گفته شد براى تحليل جغرافيايى از روش , آنا

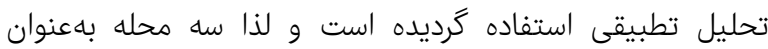

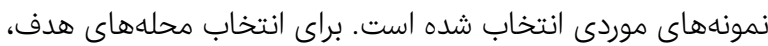
در ابتدا محلات شهر اهواز براساس شاخصهاى مكانى در ع بخش،

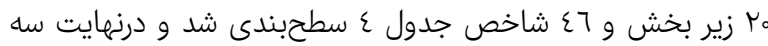

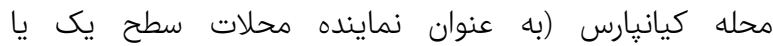
توسعهيافته)، كَلستان (به عنوان نماينده محلات سطح دوريه يات متوسط) و منبع آب با (به عنوان نماينده محلات سطح سه يان يا سطح توسعه يايين) براى مطالعه انتخاب شدند.

جدول r) ابعاد و شاخصهاى منتخب يزّوهش

\begin{tabular}{|c|c|c|}
\hline شاخص & ابعاد & متغير \\
\hline 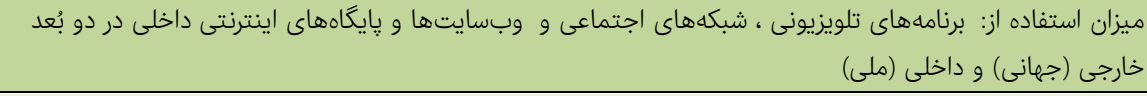 & & مستقل (ICT) \\
\hline 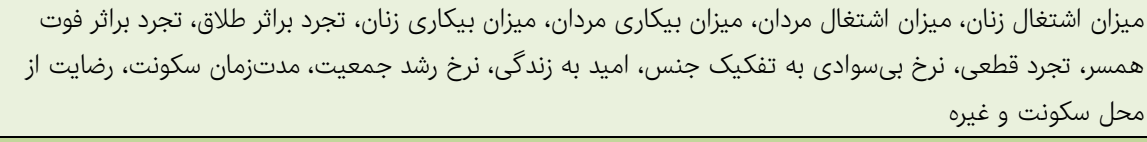 & كيفيت زندگى، قشربندى & واسط (مكان) \\
\hline 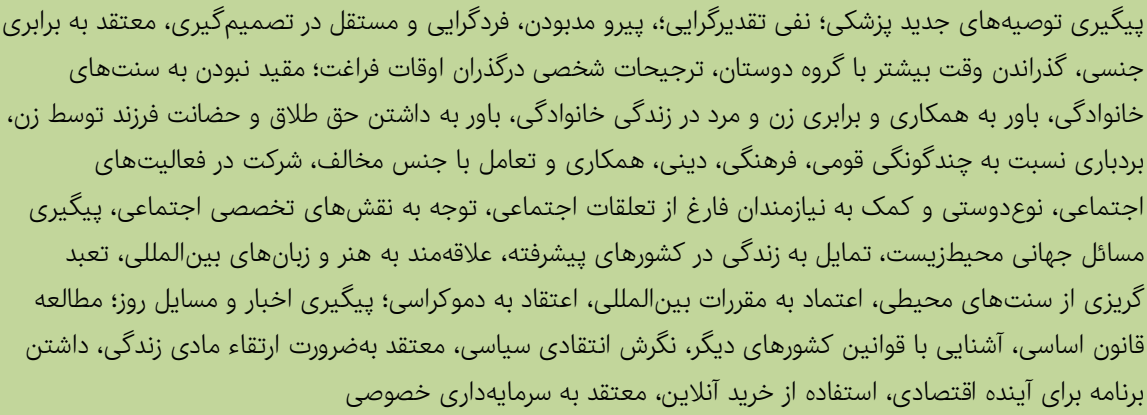 & 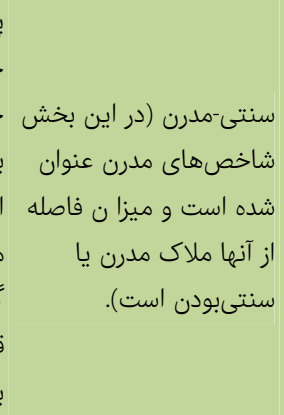 & 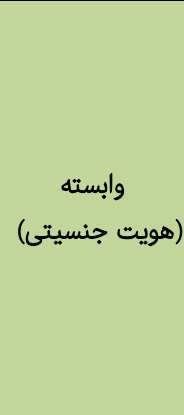 \\
\hline
\end{tabular}

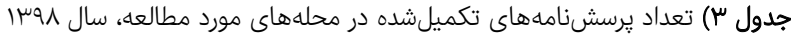

\begin{tabular}{|c|c|c|c|}
\hline رده & محله & جمعيت زنان بالاى ها سال (هوسا) & تعداد يرسشنامه \\
\hline$r$ & كيانيارس & MIIro & rod \\
\hline k & كلستان & IERMD & ir. \\
\hline 4 & منبع آب & $10 \mu M 1$ & $9 \Delta$ \\
\hline \multicolumn{2}{|c|}{ جمع } & kYyYs & F。o \\
\hline
\end{tabular}


جدول F) شاخصهاى منتخب يزّوهش براى سطحبندى محلات شهر اهواز، سال روسا

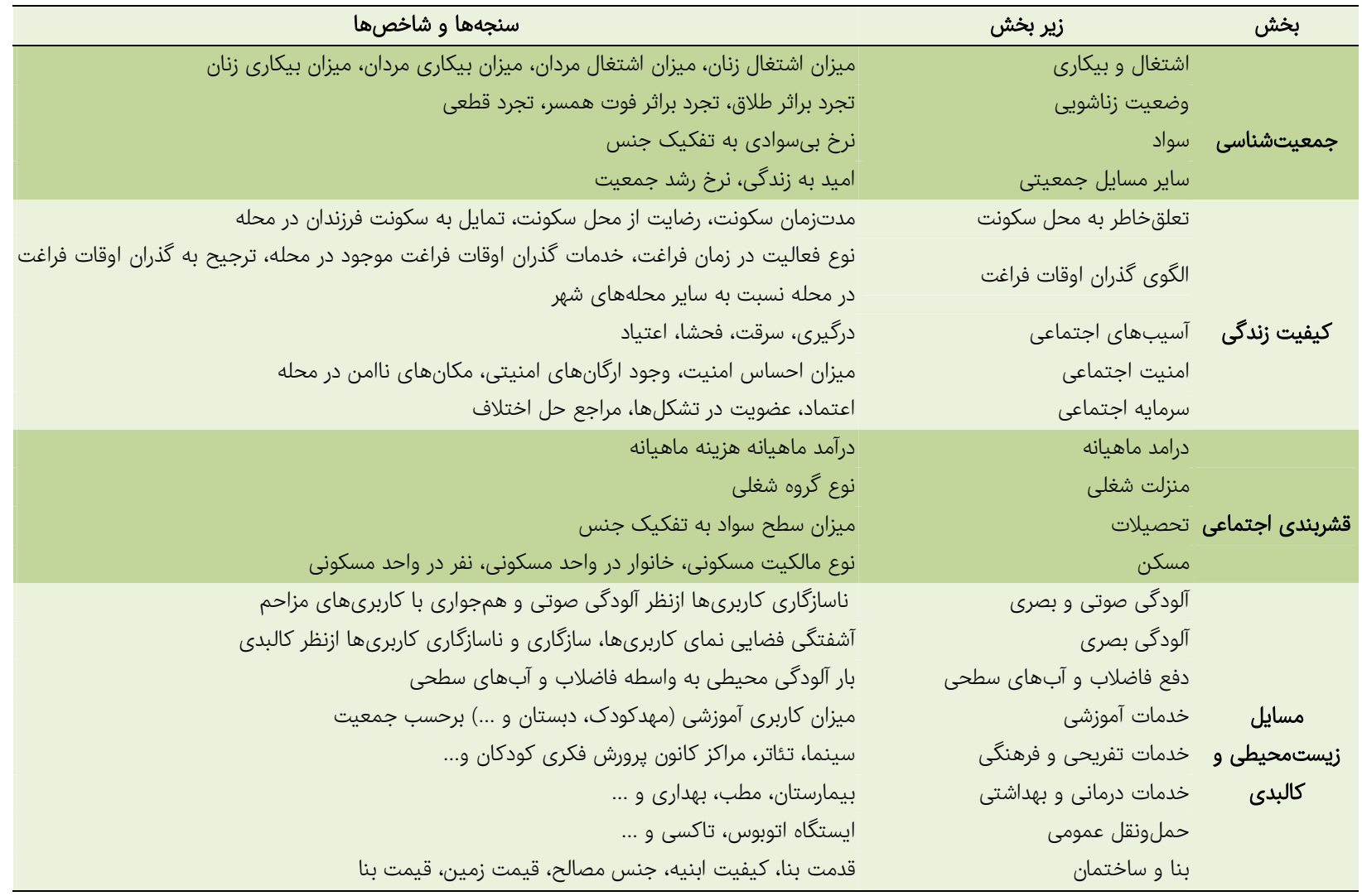

نظركَرفتن مقدار آماره f به دست آمده كه عدد قابلتوجهى است

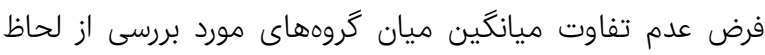

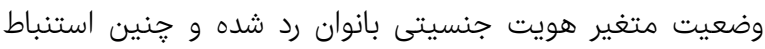

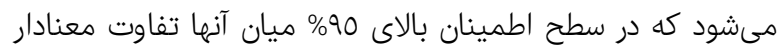
وجود دارد. با توجه به تأييد وجود تفاوت معنادار ميانكين كروهها، جهت تحليل

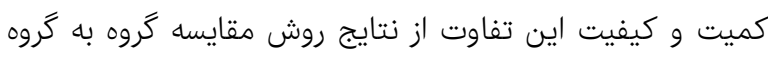
آزمون تعقيبى توكى Tukey) استفاده شد. با توجه به ندائ نتايج به دست آمده از آزمون تعقيبى توكى جدول

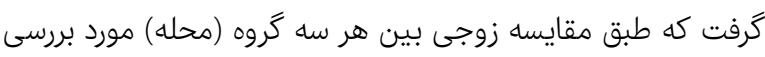

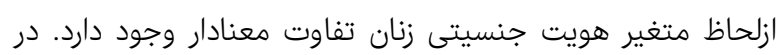

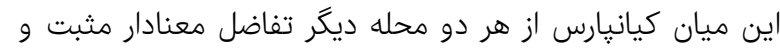

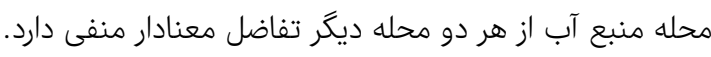

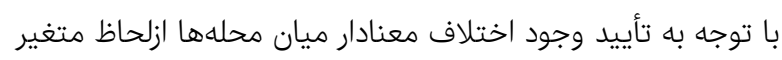

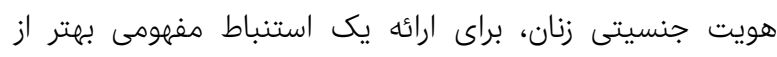

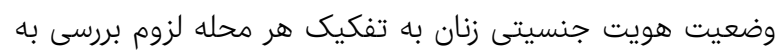

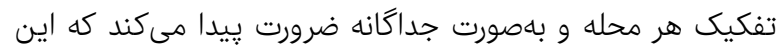

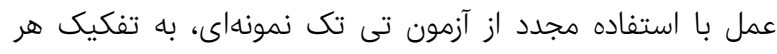

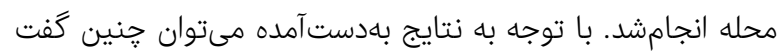

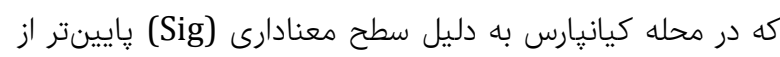

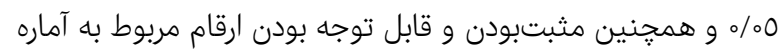

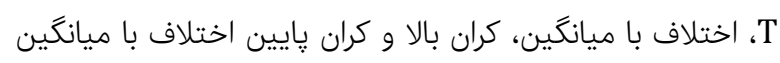

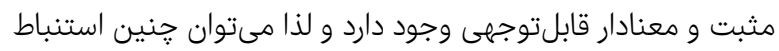

يافتهها

براى سنجش هويت جنسيتى بانوان در مجموع نمونهاى مورد

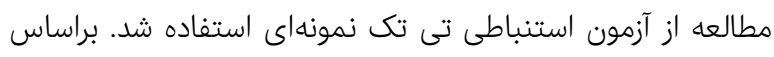

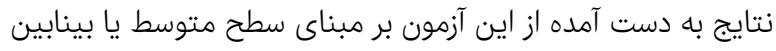

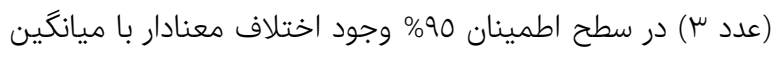

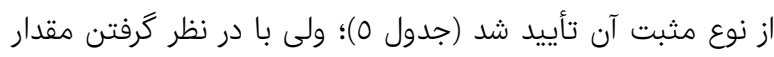

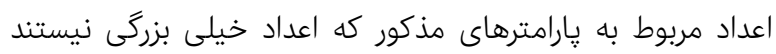

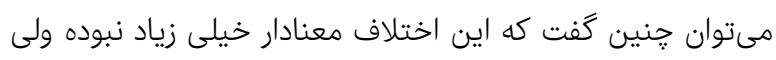

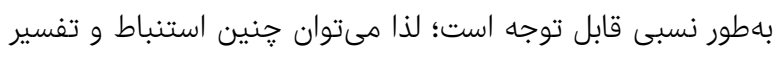

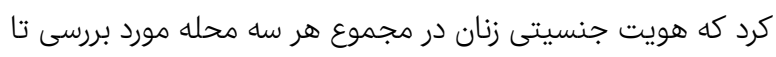

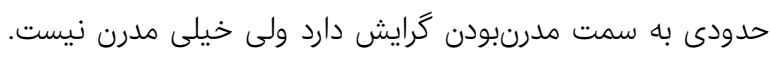

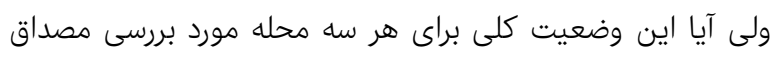

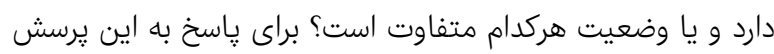

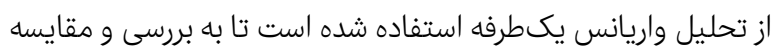

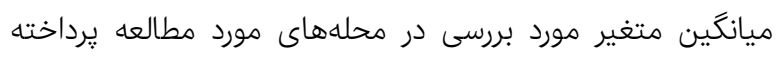

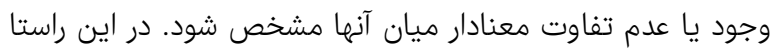

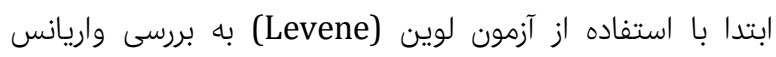

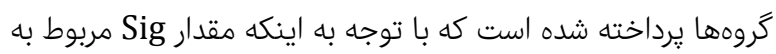

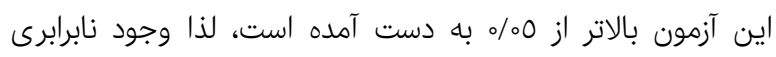

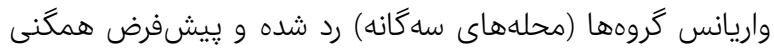

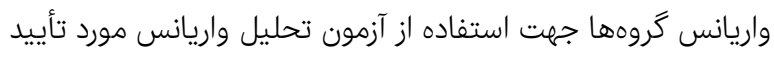

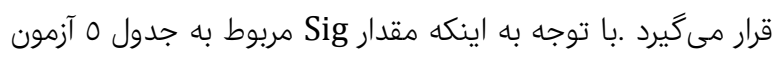

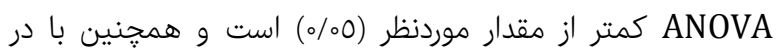


هر كدام به تنهايى بالاى سَ/ه از تغييرات متغير وابسته را ييشبينى

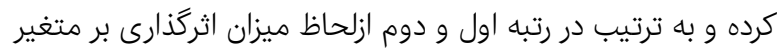

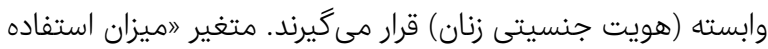

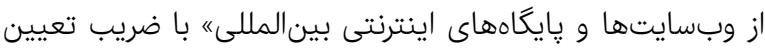

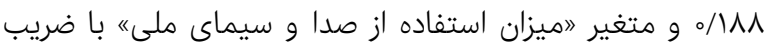

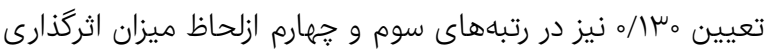

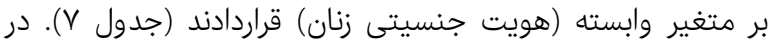

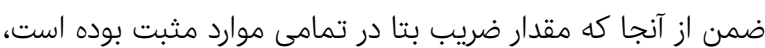
لذا جهت اثرگذارى نيز مستقيم و مثبت بوده است؛ به إنها اين مفهوم

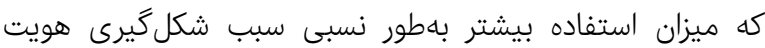

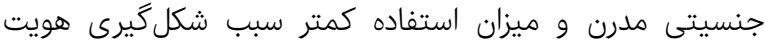
جنسيتى سنتى براى زنان بوده است؛ اما آيا اين وضعيت دئن در هر سه سه

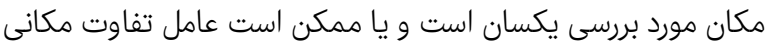

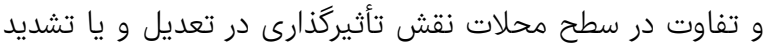
وضعيت ايفا كند؟ تونج

براى پاسخ به اين يرسش، از فرمول دوم آزمون جاو استفاده شد كه

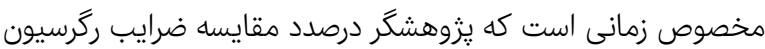
در بين بيش از دو گروه يا خط رگرسيون باشد. آماره انجام آزمون

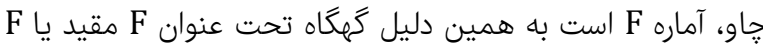

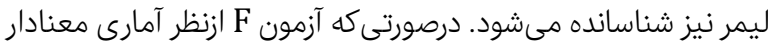

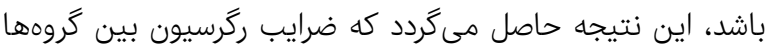

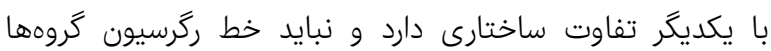

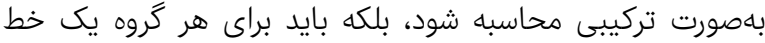

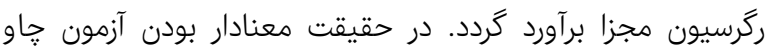

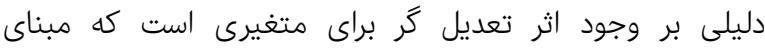

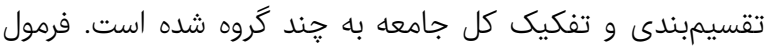
$F=\left[\frac{R S S_{\text {combined }}-\Sigma R S S_{j}}{\Sigma R S S_{j}}\right] *\left(\Sigma n_{j}-\mathrm{jk}\right.$

$$
-j) /[(j-1)(k+1)]
$$

مجموع مجذورات باقىمانده از كليه مشاهدات: RSS

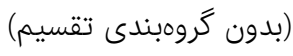

]: تعداد كروهها

jهرو

莎

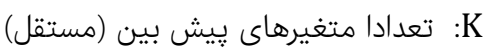

فرمول محاسبه مقدار بحرانى: קس از اجراى مجدد مدل رگرسيون خطى به تفكيك هر سه محله

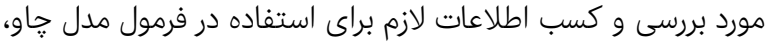

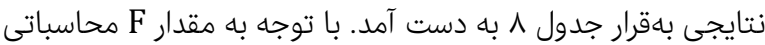

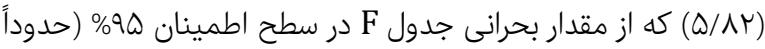

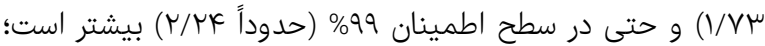

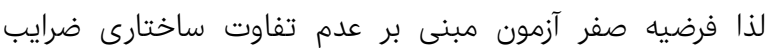

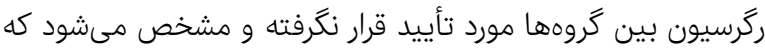

كرد كه در محله كيانيارس هويت جنسيان هيتى زنان زنان تا حدود زيادى از

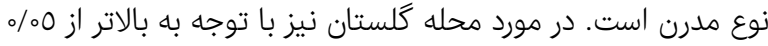

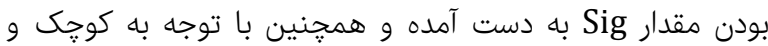

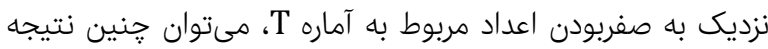

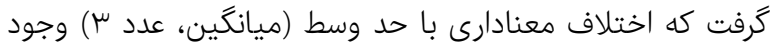
ندارد و جنين استنباط مىشود كه هويت جنسيتى زناس مدان در محله

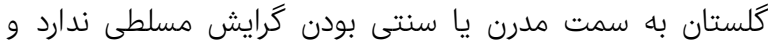

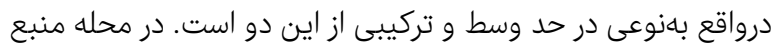
آب با توجه به كمتر از 0٪

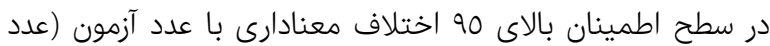

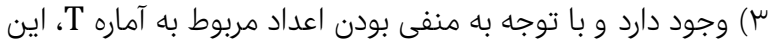

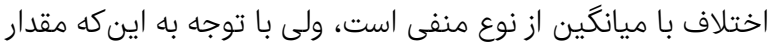

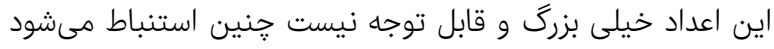
كه هويت جنسيتى زنان در محله منبع آب تا حدودى سنتى است.

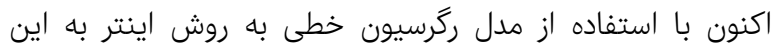

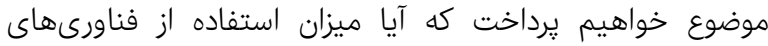
اطلاعاتى و ارتباطى در تعيين هويت جنسيتى زنان در هر هر سه محله

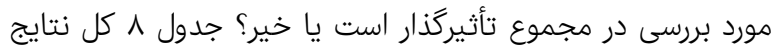

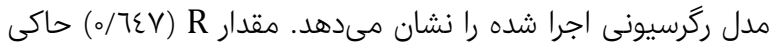

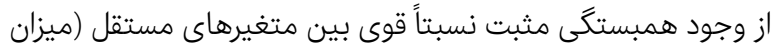

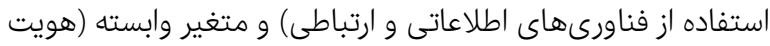

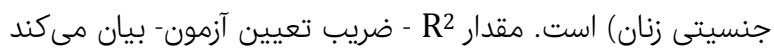

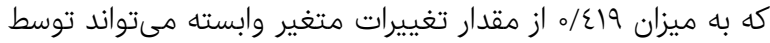

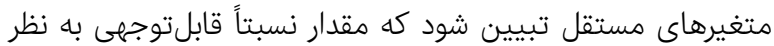
مىرسد. جهت بررسى استقلال خطاها- بهعنوان يكى از مفروضههاى

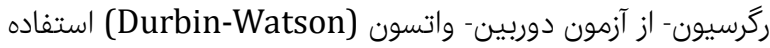

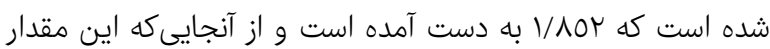
در بازه 1/0 و تا r/0 قرار دارد، لذا جاى نكرانى در مورد وجود بله همبستگى بين خطاها وجود نداشته و برقرارى شرط استقلال خطاها مورد تأييد قرار مىگيرد. با توجه به مقدار .Sig مربوط به به بـ آزمون

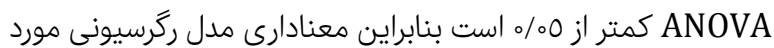

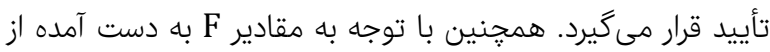

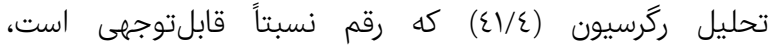
مناسببودن مدل رگرسيونى جهت تبيين تغييرات متغير وابسته

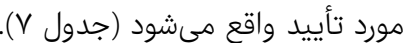

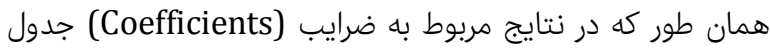
V، قابل مشاهده است مقدار Sig. مربوط به متغيرهاى لهيزان

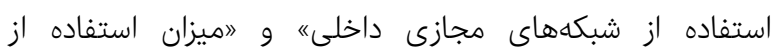

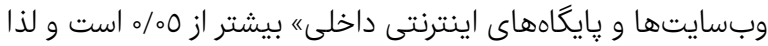

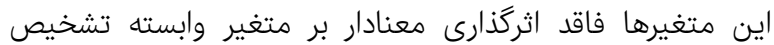

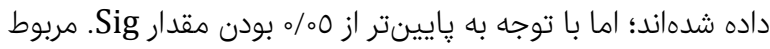

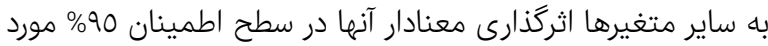

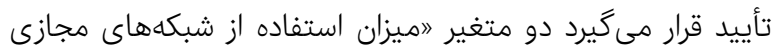

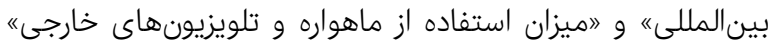


نقش مكان در اثرگذارى فناورى اطلاعات و ارتباطات بر هويت جنسيتى زنان... FM

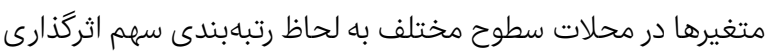
ضرايب رگرسيون بين گروهها (محلهها) با يكديخر تفاوت ساختارى

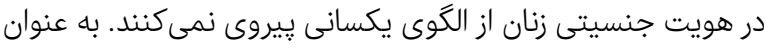

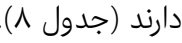

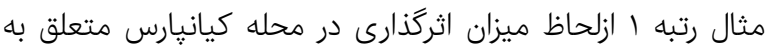

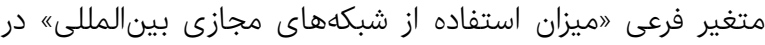

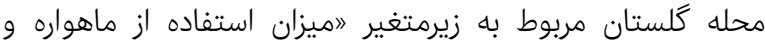

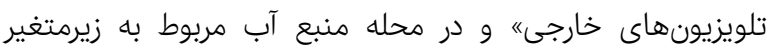
"ميزان استفاده از صدا و سيماى ملى" بوده است. اين جابجايى و

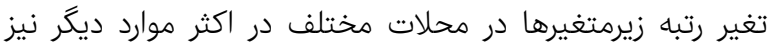

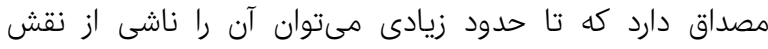

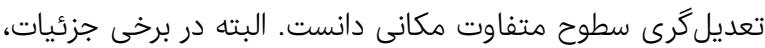
استثناها و اشتراكات قابل توجهى ميان هر سه محله نيز وجود دارد؛

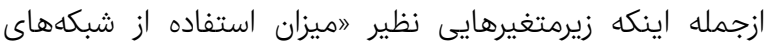

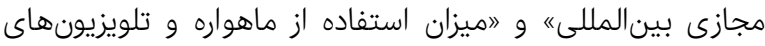
خارجى" در هر سه محله داراى اثرگذارى معنادار و متغير فرعى هـ

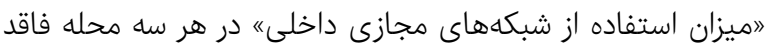

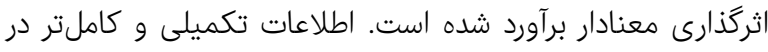
خصوص سهم و رتبه اثركذارى تمامى زير متغيرهاى مستقل (ميزان

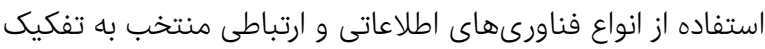

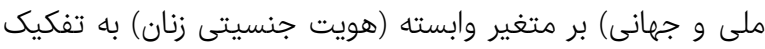

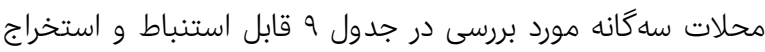
فناورىهاى اطلاعاتى و ارتباطى بر هويت جنسيتى زنان در محلات

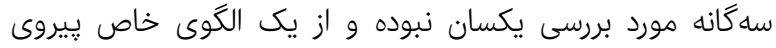
نمى كند؛ بلكه متغير مكان -يا تفاوت در سطح مكانهان بودها- در اين زمينه

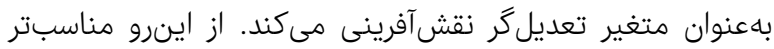

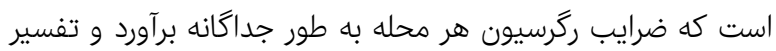

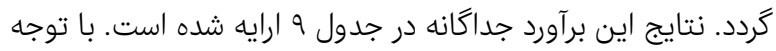

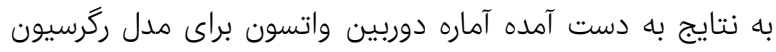

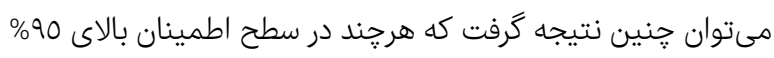
مناسببودن مدل ركرسيونى جهت تبيين تغييرات متغير وابسته

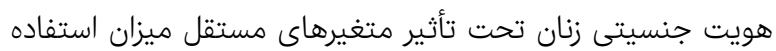

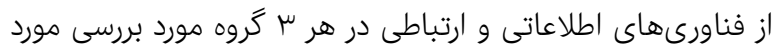

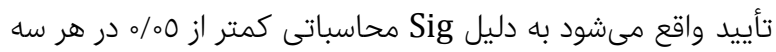
مورد ولى مقدار اين ضريب تعيين در محلات مختلف متفاوت است

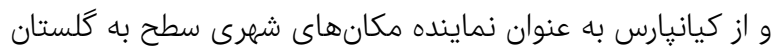
و درنهايت منبع آب به عنوان نماينده مكانهاى شيان شهرى سطوح

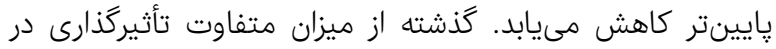

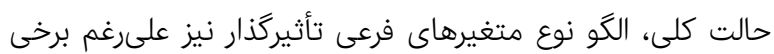

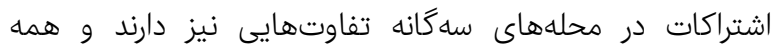

جدول ه) نتايج آزمون تى تك نمونهاى سنجش هويت جنسيتى بانوان درمجموع نمونههاى مورد مطالعه

\begin{tabular}{|c|c|c|c|c|c|c|}
\hline \multicolumn{6}{|c|}{ آزمون تى تك نمونهاى (سطح متوسط=سم) } & \multirow{3}{*}{ ميانكين } \\
\hline & & \multirow{2}{*}{ اختلاف ميانكين } & \multirow{2}{*}{ 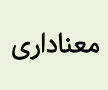 } & \multirow{2}{*}{ درجه آزادى } & \multirow{2}{*}{ آماره تى } & \\
\hline بيشترين & كمترين & & & & & \\
\hline 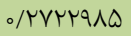 & ס & / / YTTA1007 & $\%$ & rq9 & $9 / \wedge_{0} \varepsilon$ & ץ/YYTA107 \\
\hline
\end{tabular}

جدول ع) نتايج آزمون تعقيبى Tukey (مقايسه جندگًانه) تحليل واريانس متغير هويت جنسيتى بانوان در محلات سهُانه مورد بررسى

\begin{tabular}{|c|c|c|c|c|c|c|}
\hline \multicolumn{2}{|c|}{ سطح اطمينان 90 درصد } & \multirow{2}{*}{ درجه آزادى } & \multirow{2}{*}{ خطاى برآورد } & \multirow{2}{*}{ *اختلاف ميانكين(I-J) } & \multirow{2}{*}{\multicolumn{2}{|c|}{ نام محله }} \\
\hline بيشترين حد & كمترين حد & & & & & \\
\hline 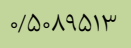 & $\circ / R 9 \Lambda \cdot \wedge \Lambda \Delta$ & $\%$ & $\%$ \% \{ 117.7 & o/E० स01991x & كلستان & \multirow{2}{*}{ كيانيارس } \\
\hline o/79У9人rา & ०/६ & $\%$ & \%००Т८৭9ह7 & 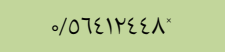 & منبع آب & \\
\hline$-0 / R 9 \Lambda \circ \wedge \Lambda 0$ & $-0 / 0.1901 \mu$ & $\%$ & $\%\{\{\wedge \wedge 17.7$ & $-0 / \varepsilon_{0}$ rolaq1 $^{x}$ & كيانيارس & \multirow{2}{*}{ كلستان } \\
\hline r & -/IVVARG & \% \% r & 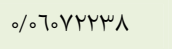 & $0 / 17070 \varepsilon 0 \Lambda^{x}$ & منبع آب & \\
\hline$-0 / \varepsilon \mu \cdot Y 77 \varepsilon$ & 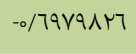 & $\%$ & 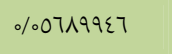 & $-0 / 07 \varepsilon \mid r \varepsilon \varepsilon \Lambda^{*}$ & كيانيارس & \multirow{2}{*}{ منبع آب } \\
\hline -o/olvrora & & $\%$ \% & \% \%.Vrrma & $-0 / 17070\left\{0 \Lambda^{x}\right.$ & كلستان & \\
\hline \multicolumn{7}{|c|}{ *|ختلاف ميانكين مناسب= 0٪ } \\
\hline
\end{tabular}

جدول V) نتايج كامل مدل تحليل رگرسيون سنجش متغير فاوا بر هويت جنسيتى درمجموع نمونههاى موردمطالعه

\begin{tabular}{|c|c|c|c|c|c|c|}
\hline \multicolumn{2}{|c|}{ دوربين-واتسون } & \multicolumn{2}{|r|}{ خطاى برآورد } & ضريب تعيين تصحيح شده & ضريب تعيين & \multirow{2}{*}{$\frac{\mathbf{R}}{0 / 7 \varepsilon V}$} \\
\hline & V/AQT & & o/ROIIFYA & $0 / 209$ & $0 / 419$ & \\
\hline معنادارى. & $\mathrm{F}$ & ميانكين & درجه ازادى & مجموع & & مدل \\
\hline$\%$ \% & $\varepsilon 1 / \varepsilon_{0} \uparrow$ & $0 / 1 \circ \varepsilon$ & 7 & $\mu_{0} / 7 \mu^{\prime}$ & & ركرسيون \\
\hline & & 每/ & $\mu_{\varepsilon O}$ & $\varepsilon r / O \mu_{\varepsilon}$ & & باقى مانده \\
\hline & & & rol & $V \Psi / 17$ 。 & & مجموع \\
\hline
\end{tabular}




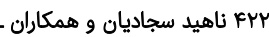

ادامه جدول V) نتايج كامل مدل تحليل رگرسيون سنجش متران متغير فاوا بر هويت جنسيتى درمجموع نمونهاى موردمطالعه

\begin{tabular}{|c|c|c|c|c|c|c|}
\hline \multirow[b]{3}{*}{ رتبه اثركذارى } & \multirow{3}{*}{ 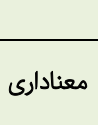 } & \multirow{3}{*}{ 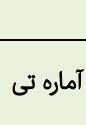 } & & & & \multirow{3}{*}{ متغيرها } \\
\hline & & & ضريب تأثير استاندارد & \multicolumn{2}{|c|}{ ضريب تأثير استاندارد نشده } & \\
\hline & & & ضريب بتا & خطاى برآورد & B & \\
\hline$\varepsilon$ & $\% 47$ & $r / 0 \varepsilon \mu$ & 0 & $\%$ \% & $0 / 101$ & ميزان استفاده از صداوسيماى ملى \\
\hline r & $\% 01$ & $0 / \wedge_{\circ}$ & 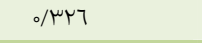 & $\% \mu \mu$ & ०/ १९६ & ميزان استفاده از ماهواره و تلويزيونهاى خارجى \\
\hline- & $\circ / 0 \vee 9$ & $\circ / 101$ & $\%$ \%० &.$/ 177$ & $\%$ & ميزان استفاده از شبكههاى مجازى داخلى \\
\hline 1 & $\%$ & 0/^৭1 & ع ع & $\% \mu_{\circ}$ & $0 / \mu_{0} r$ & ميزان استفاده از شبكههاى مجازى بينالمللى \\
\hline- & $\circ / 100$ & $1 / 0.7$ & $\%$ & $\%{ }^{\mu}$ & $\% \Leftarrow q 9$ & ميزان استفاده از وبسايتها و پايكاههاى اينترنتى داخلى \\
\hline$\mu$ & $\%$ \% & r/६OH & $\circ / \wedge \Lambda$ & $\% 01$ & o/llr & ميزان استفاده از پايكاههاى اينترنتى بينالمللى \\
\hline
\end{tabular}

جدول ^) نتيجه نهايى آزمون جاو براى ارزيابى فرض تعديلَّى متغير تفاوت مكانى در اثريذيرى هويت جنسيتى زنان از فاوا

\begin{tabular}{|c|c|c|c|c|c|c|c|}
\hline$R_{S S_{\text {combined }}}$ & $\sum R S S_{j}$ & $\sum \boldsymbol{n}_{j}$ & $\mathbf{j}$ & $\mathbf{k}$ & $\mathbf{F}$ & $F_{((j-1)(k+1)),\left(\sum n_{j}-j k-j\right)}$ & نتيجه \\
\hline$\varepsilon r / O \mu \varepsilon$ & $\mu \varepsilon / 99 \vee \mu \mid$ & $\varepsilon_{00}$ & $\mu$ & 7 & Q/А५৭q४V & $F_{(14,79)}$ & عدمتأييد \\
\hline
\end{tabular}

جدول 9) نتايج كامل مدل تحليل رگرسيون سنجش متغير فاوا بر هويت جنسيتى به تفكيك محلات سهگانه مورد بررسى

\begin{tabular}{|c|c|c|c|c|c|c|c|}
\hline \multicolumn{3}{|c|}{ دوربين-واتسون } & خطاى برآورد & ضريب تعيين تصحيح & ضريب تعيين & $\mathrm{R}$ & نام محله \\
\hline \multicolumn{3}{|c|}{$r / I I I$} & $\circ / \mu \circ V V \circ \gamma^{\mu} \varepsilon$ & 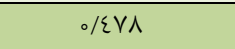 & ०/६१७ & $\circ / V \circ \varepsilon$ & كيانيارس \\
\hline \multicolumn{3}{|c|}{ r/rVq } & ०/r799人स07 & $\circ / \mu \varepsilon 7$ & $\circ / \mu \vee q$ &.$/ 717$ & كلستان \\
\hline \multicolumn{3}{|c|}{$1 / 119$} & ०/Or $11.9 \varepsilon 7$ & ०/TIA & $\circ / T V_{0}$ &.$/ 019$ & منبع آب \\
\hline \multicolumn{8}{|c|}{ آنوا } \\
\hline معنادارى & آماره اف & ميانكين & درجه آزادى & مجموع & & مدل & نام محله \\
\hline \multirow[t]{3}{*}{$\%$} & \multirow[t]{3}{*}{ KN/YIV } & \multirow{3}{*}{$\begin{array}{l}r / 7 V r \\
\circ / \circ 90\end{array}$} & 7 & $17 / \mu_{0}$ & \multirow{3}{*}{\multicolumn{2}{|c|}{ برقى راقيون }} & \\
\hline & & & IVT & $17 / Y \wedge T$ & & & كيانيارس \\
\hline & & & IVA & & & & \\
\hline \multirow[t]{3}{*}{ ०००० } & \multirow[t]{3}{*}{$11 / \varepsilon_{0} \Lambda$} & 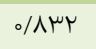 & 7 & $\varepsilon / 9 \wedge 9$ & \multirow{3}{*}{\multicolumn{2}{|c|}{ رَّرس مديون }} & \\
\hline & & $\circ / V^{\mu}$ & $11 \pi$ & $\Lambda / 17 \varepsilon$ & & & كلستا.. \\
\hline & & & 111 & س & & & تان \\
\hline \multirow[t]{3}{*}{$\% 001$} & \multirow[t]{3}{*}{$0 / Y 70$} & I/OrV & 7 & $7 / 1.9$ & \multicolumn{2}{|r|}{ مدل } & \\
\hline & & $\circ / r q_{0}$ & or & $10 / 0 \varepsilon \Lambda$ & \multirow{2}{*}{\multicolumn{2}{|c|}{ برقى ريون مانده }} & منبع آب \\
\hline & & & 71 & $17 / 70 \mathrm{~V}$ & & & \\
\hline
\end{tabular}

\section{ضرايب}

\begin{tabular}{|c|c|c|c|c|c|c|c|}
\hline \multirow{2}{*}{ اثرگذارى } & \multirow{2}{*}{ درجه آزادى } & \multirow{2}{*}{ 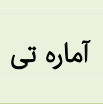 } & \multirow{2}{*}{ ضريب تأثير استاندارد } & \multicolumn{2}{|c|}{ ضريب تأثير استاندارد نشده } & \multirow{2}{*}{ متغيرها } & \multirow{2}{*}{ نام محله } \\
\hline & & & & خطاى برآورد & B & & \\
\hline- &.$/ \mu$ & $\circ / 071$ & $\circ \varepsilon_{0}$ & $\circ / 1 \Lambda$ & $\%$ \% & ميزان استفاده از صداوسيماى ملى & \multirow{6}{*}{ كيانيارس } \\
\hline$r$ & $\circ \% 01$ & $\varepsilon / 9 \wedge\rceil$ & $\circ / \mu r_{0}$ & $\% 70$ & $\circ / T \varepsilon 1$ & ميزان استفاده از ماهواره و تلويزيونهاى خارجى & \\
\hline- & $\circ / 0 \wedge \Lambda$ & $\circ / 0 \varepsilon \mu$ & $\% \mu_{\circ}$ & $\% 19$ & \%०८ & ميزان استفاده از شبكههاى مجازى داخلى & \\
\hline 1 & $\circ / 000$ & $7 / 010$ & $\circ /$ roג & $\circ \%\{7$ & $\circ / r V V$ & ميزان استفاده از شبكههاى مجازى بين المللى & \\
\hline- & $\circ / \mu 11$ & $1 / 017$ & $\%$ & $\circ \circ r \varepsilon$ & \% ro & ميزان استفاده از پايگاههاى اينترنتى داخلى & \\
\hline$\mu$ & $\circ \% \wedge$ & $\mu / q_{0 \circ}$ & $\circ / 49 \Lambda$ & $\circ \%$ & o/NAr & ميزان استفاده از پايگاههاى اينترنتى بينالمللى & \\
\hline$\varepsilon$ & $\circ \% \mu \varepsilon$ & $r / 101$ & $\circ / \Lambda \vee V$ & $\circ \%\{9$ & $\circ / 1 \circ \varepsilon$ & ميزان استفاده از صداوسيماى ملى & \multirow{6}{*}{ كلستان } \\
\hline 1 & $\circ \% \circ$ & $\varepsilon /$ ror & $\circ / \mu \circ 9$ & 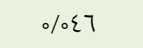 &.$/ 197$ & ميزان استفاده از ماهواره و تلويزيونهاى خارجى & \\
\hline- & $\circ / 1 \mu$ & $1 / r \varepsilon_{0}$ & $\% 90$ & $\%$ & $\circ \% \mu$ & ميزان استفاده از شبكههاى مجازى داخلى & \\
\hline r & $\% \circ 0$ & $\varepsilon / \circ 0 \varepsilon$ & $\left.\circ / \mu_{0}\right)$ &.$\% 77$ & $\circ / \curlywedge \wedge$ & ميزان استفاده از شبكههاى مجازى بينالمللى & \\
\hline- & $\circ \%$ & YOMI & $\circ \vee \vee \varepsilon$ & $\circ \% \mu$ & س & ميزان استفاده از يايگاههاى اينترنتى داخلى & \\
\hline$\mu$ & .017 & r/Ooo & $\circ / r \mu \Lambda$ &.$\% 07$ & $\circ / 1 \mu q$ & ميزان استفاده از پايكاههاى اينترنتى بين المللى & \\
\hline 1 & $\% \circ 0$ & $\varepsilon / 077$ & $\circ / \mu / \varepsilon$ & $\circ \% \mu^{\mu}$ & 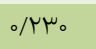 & ميزان استفاده از صداوسيماى ملى & \multirow{6}{*}{ 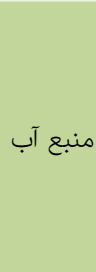 } \\
\hline$r$ & $\circ \circ \mathrm{V}$ & $\mu / 709$ & $\circ /$ roג & $\circ \circ \varepsilon q$ & $\circ / 1 \vee 7$ & ميزان استفاده از ماهواره و تلويزيونهاى خارجى & \\
\hline- & $\circ / 114$ & $1 / \mu q_{0}$ & $\circ / \wedge \Lambda$ & $\circ \odot \varepsilon$ & $\% \varepsilon r$ & ميزان استفاده از شبكههاى مجازى داخلى & \\
\hline$\mu$ & $\% 11$ & $\mu / \varepsilon 00$ & 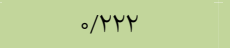 & 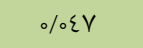 & ॰/\乏〉 & ميزان استفاده از شبكههاى مجازى بينالمللى & \\
\hline$\varepsilon$ & \% & $1 / 911$ & ०/०9r & $\circ / \% q$ & $\circ \% 9$. & ميزان استفاده از پايگاههاى اينترنتى داخلى & \\
\hline- & 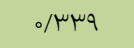 & $\circ / 071$ & $\%$ \% & $\circ \circ{ }_{1}$ & \% HA & ميزان استفاده از پايگاههاى اينترنتى بينالمللى & \\
\hline
\end{tabular}




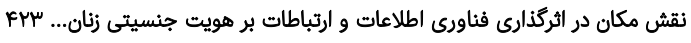

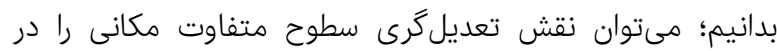

كيفيت فرايند شكل

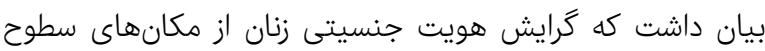
بالاتر به سمت مكانهاى سطوح يايينتر تغييريافته و از مدرنبودن

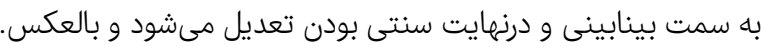

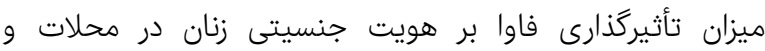
مكانهاى شهرى سطوح بالاتر و توسعايافتهاتر، بيشتر و در محلات سطوح يايينتر و كمتر توسعهيافته، كمتر است. كذشته از از ميزان

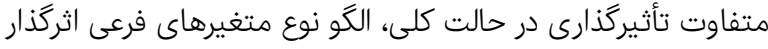

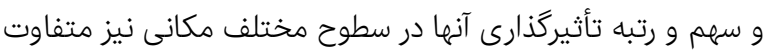

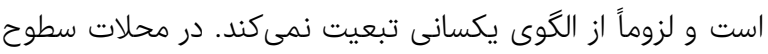

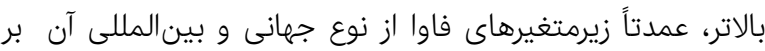

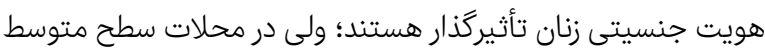
نقش اثرگذارى زيرمتغيرهاى جهانى و بين المللى فاوا كمى تعديل

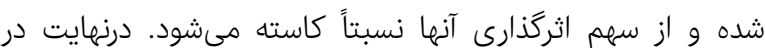
محلات و مكانهاى سطوح يايينتر (سطح سوم) سهم زيرمتغيرهاى

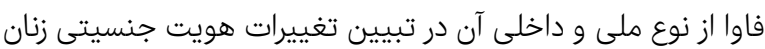
به نسبت محلات سطوح بالاتر، بيشتر مىشود؛ هرجند هنوز غلبه اصلى تا حدودى متعلق به متغيرهاى جهانى و بين المللى فاوا است.

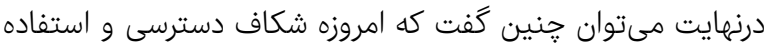

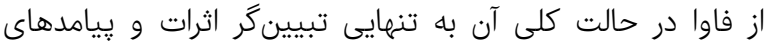

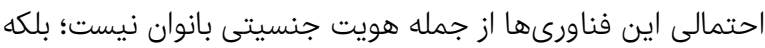

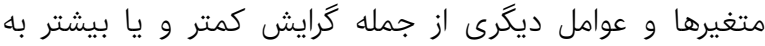

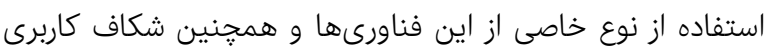

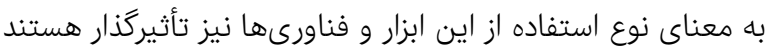

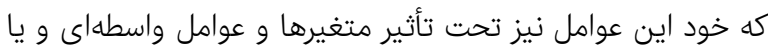
تعديلگ مانند تفاوت مكانى قرار دارند.

تشكر و قدردانى: سياس و قدردانى از بانوان و خانوادههاى محترم

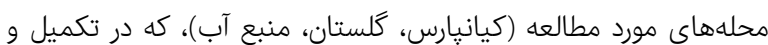

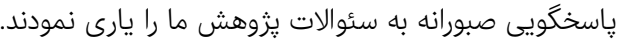

تأييديه اخلاقى: موردى از سوى نويسندكان گزارش نشده است.

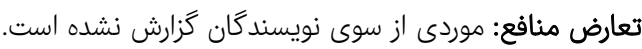

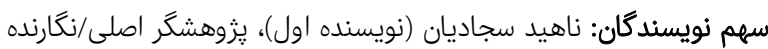

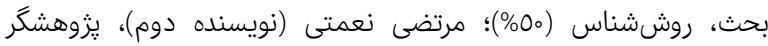

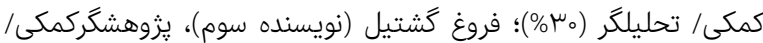

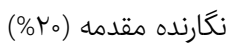
منابع مالى: اين مقاله مستخرج از رساله دكترى با عنواند" مغاندان تحليل

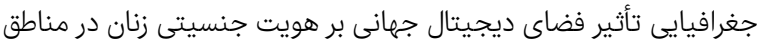

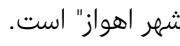

منابع

Abassi Ghaderi M, Khalili Kashani M (2013). The effect of the internet on national identity. Tehran: Strategic Studies Research Center. [Persian]
به طور كلى يافتههاى اين :يزوهش؛ تعديلگرى نقش مكان و تفاوتهاى مكانى بر اثرگذارى عوامل خارج از محيط-در اينجا فاوا-

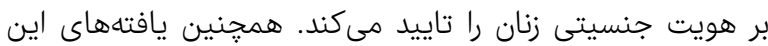

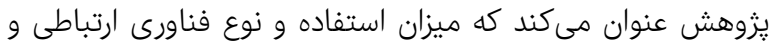

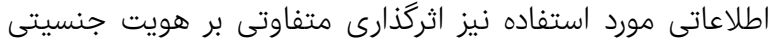

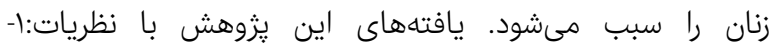
جغرافيدانان جنسيت (جكسون) كه معتقدند:شكل

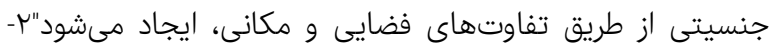
نظريه كاشت گربنر مبنى بر اينكه "مواجها به با رسانهاى خاص،

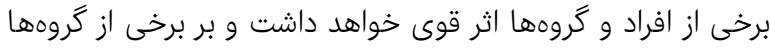
تأثيرى نخواهد كذاشت"، س- نظريه استفاده و رضايتمندى كرى كه بيان مى كند:"در روابط بين رسانهها و متغيرهاى فردى و مكانى، معمولاً

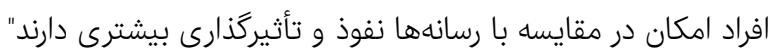
ع- با ديدگًاه هويت اجتماعى جنكينز كه معتقد است "زمان ورسان و مكان

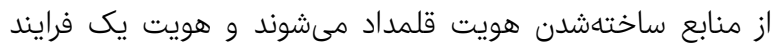
مستمر است كه در طى زمان توليد و بازتوليد مىشود"، مطابقت

همجنين يافتههاى اين يزوهش، نتايج يزوهشهاى: جكسون [Davael \& Masii, 2010] دوائل و ماسى :Jacsoon, 1993]

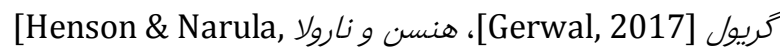
[2009، تابان و همكاران [Taban et al, 2013]، رضوانى و و

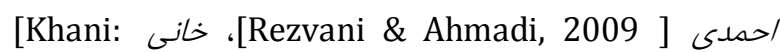

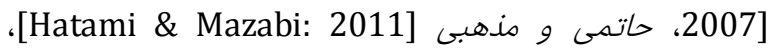
[Nikkhah Ghamsari \& نيكخوامقمصىى و منصوريان راوندى

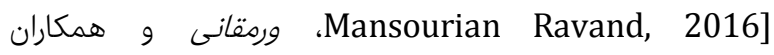
[Khajeh [Varmaghani et al, 2015] [Ahmadi \& Aghili, احمدى و عقيلى (Noori et al, 2011] [2015، عالىيور [Adlipoor, 2012]، افشاركهن و كرمانجى [Afsharkohan \& Kermanji, 2017] كاشانى [Abasi Ghaderi \& Khalili Kashani, 2013] را مبنى بر اثرگذارى مكان و فاوا بر هويت به طور كلى و هويت جنسيتى

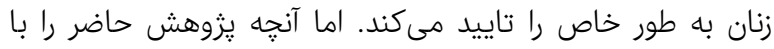

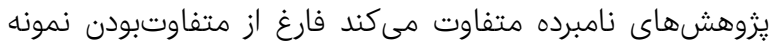

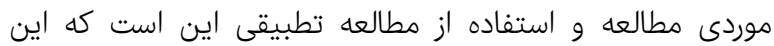

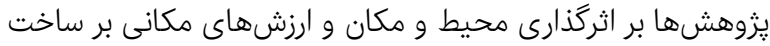

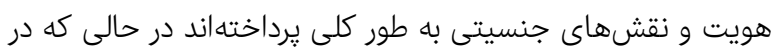

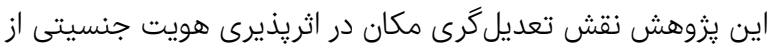

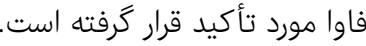

نتيجه گيرى

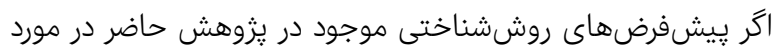

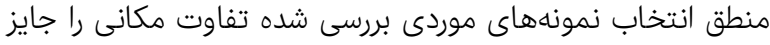

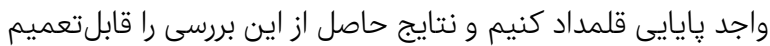


Henson J, Narula A (2009). New communication technologies in developing countries. Heydari D, translator. Tehran: Media Studies Research Center. [Persian]

Jackson C (1993). Doing what comes naturally? Women and environment in development. World Development. 21(12):1947-1963.

Jay Dunn R (2005). The social critique of postmodernism. (Translator: Saleh Najafi). Tehran: Pardis Danesh.

Jenkins R (2012). Social identity. $4^{\text {th }}$ ed. New York: Routledge.

Khajeh Noori B, Parnian L, Hemmat S (2016). The relationship between lifestyle and social identity case study: Young people Bandar Abbas. Journal of Cultural Iranian Research. 7(1):69-94. [Persian]

Khani F (2007). In the field of gender geography. Tehran: Samt. [Persian]

Mohammadi Asl A (2011). Gender and geography. Tehran: Golazin. [Persian]

Movahed A, Zarifi K (2011). Investigating the socioeconomic dimensions of the eighth marginal area of Ahvaz. The First Urban Economics Conference of Iran. Tehran. [Persian]

Mehdizadeh M, Tofighi M (2006). Presentation relationship in virtual space and modern identity. Journal of Resaneh (Media). 26(3):179-200. [Persian]

Nemati M (2011). Transformation of space-time concepts in the information society; the necessity of reviewing the fundamental geographical information systems. Journal of Information and Communication Technology of Iran. 1(1):44-56. [Persian]

Nikkhah Ghamsari N, Mansourian Ravandi F (2016). Research of relationship between virtual space and gender identity case study of Internet Users in Kashan City. Journal of Media Studies. 9(27): 107-120. [Persian] Oraki P (2015). Geographical analysis of factors influencing social security from the viewpoint of citizens; case study of Izeh City [dissertation]. Ahvaz: Shahid Chamran University of Ahvaz. [Persian]

Papoli Yazdi MH, Sahaghi M (2002). Tradition, modernity, reviewing an article: Geography is Human Interaction, Culture, Technology, Management, and Environment. Quarterly Journal of Geographical Research. 17(3-2):831. [Persian]

Persian Language and Literature Academy (2018). Word Dictionary Group. "Farsi. Second Office. Culture Dictionary Approved by the Academy. Tehran: Persian Language and Literature Academy. [Persian]

Link:

Seyfollahi S, Razeghian A (2008). Social factors affecting women's gender identity in Iran; case study: Tehran. Journal of Social Sciences Research. 2(3):27-54. [Persian] Rezapour D, Chenani Nasab H, Bagheri R (2016). Investigating the relationship between socialization and gender identity case study: female students of payam noor Dezful university. Journal of Woman in Culture and Art. 8(3):333-348. [Persian]

Sadeghi Givi M, Parhizkari B (2010). Explaining the components of the traditional and modern women's identity in poetry Parvin Etesami. Journal of Farsi Language and Literature. 3(20):207-227. [Persian]

Taban M, Pour Jafar M, Pourmand H (2013). Identity and location, phenomenological approach. HOVIATESHAHR. 6(10):79-90. [Persian]

Varmaghani H, Sultanzadeh H, Mizan Dehbashi S (2015). The relationship between gender and space in the private Ahmadzadeh Kermani R (2011). Rethinking in culture and media. Tehran: Chapar. [Persian]

Adlipoor S (2013). Sociological explanation of the consequences of virtual social networks on the social identity of Isfahan [dissertation]. Isfahan: Isfahan University. [Persian]

Afsharkhan J, Rezaei Karmajani M (2017). Investigating the role of social identity in determining the lifestyle of young people case study: Hamadan City. Quarterly Journal of Social Sciences. 4(1):157-188. [Persian]

Ahmadi S, Aghili V, MehdiZadeh M, Mozafari A (2015). Media and reproduction of women's gender identity case study: Representation of women's gender identity in"Zamaneh "and" Tekieh bar bad. Quarterly Journal of Communication Research. 22(81):35-56. [Persian]

Bigdeli Z, Sharifi S (2008). An introduction to the concept of location. Journal of Library and Information Science. 11(4):239-254. [Persian]

Bostan H (2009). Islam and gender differences. Qom: Howzwh and University Research Institute.

Bastani S, Mousainejad P (2013). Gender identity of men and women in Tehran metropolitan area. Journal of Social and Psychological Studies of Women. 11(2):29-54. [Persian]

Behnam J (2012). Iranians and Modern Thought. $4^{\text {th }}$ ed. Tehran: Farzan Roz.

Damanbagh S (2013). Geographic analysis selected indicators of urban quality of life case study: Kianpars, Golestan, and Ameri neighborhoods [dissertation]. Shahid Chamran University of Ahvaz. [Persian]

Deputy of Planning and Development of Ahvaz Municipalities (2018). Ahvaz Municipality Statistics. [Persian]

Flint C (2006). Introduction to Geopolitics. New York: Routledge.

Ghanavati $\mathrm{T}$ (2013). Geographic analysis of social inequalities in Ahvaz (Case Study: Shahrak Naft, Golestan, Hassirabad) [dissertation]. Ahvaz: Shahid Chamran University of Ahvaz. [Persian]

Ghanbari A (2015). Geography and place identity in the age of globalization. Quarterly Journal of Geographical Research. 29(112):161-192. [Persian]

Grewal M (2017). Mass media and the reconfiguration of gender identities: The Bharatiya Nari in the United States. Gender Technology and Development. 7(1):53-73.

Gregory D, Janston R, Pratt G, Watts MJ, Watts S, editors (2000). The dictionary of human geography. $5^{\text {th }}$ ed. New York: Wiley-Blackwell.

Giddens A (2012). Gender Sociology. (Sabouri M: Translator). Tehran: Ney. [Persian]

Giddens A (1992). Modernity and self-Identity, self and society in the late modern age. Cambridge: Polity Press.

Hekman S (2007). Identity crises, identity, identity politics, and beyond. Journal of Critical Review of International Social and Political Philosophy. 2(1):3-26.

Hafez Nia MR, Ahmadipour Z, Qaderi Hajat M (2008). Politics and Space. Mashhad: Papoli. [Persian]

Hafez Nia MR (2009). Introduction to Research Methods in the Humanities. Tehran: Samt. [Persian]

Hatami MR, Mazhabi S (2011) Media and women's attitudes to their gender identity. Journal of Iranian Cultural Researches. 4(2):185-209. [Persian]

Hemati R, Aslani S (2015). Effective factors of students' academic identity formation with emphasis on the role of the internet. Quarterly Journal of Research and Planning in Higher Education. 31(3):121-149. [Persian] 
نقش مكان در اثركذارى فناورى اطلاعات و ارتباطات بر هويت جنسيتى زنان... FrQ

Marketing. 42(3-4):299-310.

Thomas DF, Cross JE (2007). Organization as place builders. Greeley, CO: University of Northern Colorado, Department of Management Faculty Publications.

Woodward K (2004). Ouestioning Identity: Gender, Class, Nation. London: Routledge.

Wynn E, katz J (1998). Hyperbole over Cyberspace: SelfPresentation and Social Boundaries in Internet Home Pages and Discourse. The Information Society an International Journal. 13(4):297-327.

Zaki MA (2016). Internet and Iranian Identity. Journal of Information Communication. 12(37):185-206. [Persian] and general areas of the Qajar period. BAGH-E NAZAR. 12(37):29-40. [Persian]

Lorber J (2000). Using gender to undo gender: A feminist degendering movement. Journal of Feminist Theory. 1(1):79-95.

Malesevic S, Haugaard M, editors (2002). Making Sense of Collectivity, Ethnicity, Nationalism and Globalism. London: Pluto Press.

Caplan PJ, Crawford M, Hyde JS, Richardson JTE (1997). Gender Differences in Human Cogniton. New York: Oxford University press.

Simmons G (2008). Marketing to Postmodern Consumers: Introducing the internet chameleon. European Journal of 